\title{
Reconstructing the Gorte and Spiaz de Navesele Landslides, NE of Lake Garda, Trentino Dolomites (Italy)
}

\author{
Giacomo Ruggia ${ }^{1}$, Susan Ivy-Ochs ${ }^{1,2}$, Jordan Aaron ${ }^{1}$, Olivia Steinemann ${ }^{2}$, Silvana Martin ${ }^{3}{ }^{\mathbb{D}}$, Manuel Rigo ${ }^{3}{ }^{\mathbb{D}}$, \\ Sandro Rossato ${ }^{3, *}$, , Christof Vockenhuber ${ }^{2}$, Giovanni Monegato ${ }^{4}(\mathbb{C})$ and Alfio Viganò ${ }^{5}$ \\ 1 Department of Earth Sciences, ETH Zürich, Sonneggstrasse 5, 8092 Zürich, Switzerland; \\ giacomo.ruggia@sunrise.ch (G.R.); ivy@phys.ethz.ch (S.I.-O.); jordan.aaron@erdw.ethz.ch (J.A.) \\ 2 Laboratory of Ion Beam Physics, ETH Hönggerberg, Otto-Stern-Weg 5, 8093 Zürich, Switzerland; \\ okronig@phys.ethz.ch (O.S.); vockenhuber@phys.ethz.ch (C.V.) \\ 3 Department of Geosciences, University of Padova, Via Gradenigo 6, 35131 Padova, Italy; \\ silvana.martin@unipd.it (S.M.); manuel.rigo@unipd.it (M.R.) \\ 4 Institute of Geosciences and Earth Resources, National Research Council of Italy, Via Gradenigo 6, \\ 35131 Padova, Italy; giovanni.monegato@igg.cnr.it \\ 5 Servizio Geologico, Provincia Autonoma di Trento, Via Zambra 42, 38121 Trento, Italy; \\ alfio.vigano@provincia.tn.it \\ * Correspondence: sandro.rossato@unipd.it
}

Citation: Ruggia, G.; Ivy-Ochs, S.; Aaron, J.; Steinemann, O.; Martin, S.; Rigo, M.; Rossato, S.; Vockenhuber, C.; Monegato, G.; Viganò, A. Reconstructing the Gorte and Spiaz de Navesele Landslides, NE of Lake Garda, Trentino Dolomites (Italy). Geosciences 2021, 11, 404. https:// doi.org/10.3390/geosciences11100404

\section{Academic Editors:}

Hans-Balder Havenith and Jesus Martinez-Frias

Received: 25 August 2021

Accepted: 21 September 2021

Published: 25 September 2021

Publisher's Note: MDPI stays neutral with regard to jurisdictional claims in published maps and institutional affiliations.

Copyright: (c) 2021 by the authors. Licensee MDPI, Basel, Switzerland. This article is an open access article distributed under the terms and conditions of the Creative Commons Attribution (CC BY) license (https:// creativecommons.org/licenses/by/ $4.0 /)$.

\begin{abstract}
We applied a multi-method approach to reconstruct the Gorte rock avalanche $\left(85-95 \mathrm{Mm}^{3}\right)$ located at the northeastern end of Lake Garda. The combination of field mapping, characterization of bedrock discontinuities, Dan3D-Flex runout modeling and dating of boulders with cosmogenic ${ }^{36} \mathrm{Cl}$ supports the conclusion that the deposits stem from a single rock avalanche at $6.1 \pm 0.8 \mathrm{ka}$. The Gorte event may have triggered the Spiaz de Navesele-Salto della Capra landslide ( $\left.3.2 \mathrm{Mm}^{3}\right)$, whose deposits cover the southern end of the Gorte deposits. First-order controls on detachment were the NNE-SSW- and WNW-ESE-oriented fractures in the limestone bedrock, related to the Giudicarie and Schio-Vicenza fault systems, respectively. Dan3D-Flex runout modeling sufficiently reproduced the Gorte rock avalanche, which involved detachment and sliding of a quasi-intact block, likely along marly interbeds, followed by rapid disintegration. The frictional rheology in the source area and the turbulent frictional rheology (Voellmy) in the remaining part best replicate the observed deposit extent and thickness. Heavy precipitation that occurred at that time may have contributed to failure at Gorte. Nonetheless, its timing overlaps with the nearby $(<15 \mathrm{~km})$ Dosso Gardene (6630-6290 cal BP) and Marocca Principale (5.3 $\pm 0.9 \mathrm{ka})$ landslides, making a seismic trigger plausible.
\end{abstract}

Keywords: European Alps; rock avalanche; cosmogenic ${ }^{36} \mathrm{Cl}$; Dan3D-Flex runout modeling

\section{Introduction}

Large-scale gravitational events are relevant processes for understanding landscape evolution in mountainous regions and can pose a serious risk to people and infrastructure [1-3]. In the Alps, landslides, including rock avalanches, are responsible for a tragic number of casualties and economic losses. In recent decades, a growing interest in these phenomena has developed, and they are increasingly studied in all of their aspects. In particular, if landslides can runout or fall into natural lakes [4,5], or into artificially dammed lakes as in the case of Vajont (NE Italy) [6] or hydroelectric basins (Tibet, Yarlung Tsangpo Tibet 22 March 2021, https://sandrp.in/2021/03/30/massivelandslide-on-yarlung-tsangpo-on-march-22-2021/), they can produce hazard cascades, such as landslide-generated tsunamis.

Back-analysis and modeling of past rock slope failures [7,8], combined with studies on landforms, sedimentology and internal structures of landslide deposits [9-11], allow insight into movement processes and emplacement sequences [12-14]. Reconstructing the processes that occur during release and emplacement provides fundamental data on the 
reasons for past and possible future slope failures, and on the extent of possibly impacted areas [7].

Rock avalanches have also been studied as phenomena occurring in specific areas or time periods, moving the focus from a single event to a regional analysis. Clustering of some major rock slope failures in space and time has been recognized in the Alps [15-20], suggesting factors acting over vast areas and over relatively long timespans. Detailed studies on volume, release area and runout characteristics of pre-historic and historic landslides contribute to our understanding of post-glacial slope dynamics and landscape evolution $[4,13,16,21-25]$. Inaccurate interpretations of these features can lead to misleading conclusions regarding rock avalanche hazards and mechanisms.

In our study, we focused on two closely related rock avalanche deposits located in the Nago-Torbole region in the far northeastern corner of Lake Garda (Trentino Province, Italy) (Figure 1). These deposits belong to a group of landslides that are located along the shores of Lake Garda, the plain of the town of Nago and the Loppio area and are genetically related to landslides within the Sarca Valley up to the Brenta Dolomite group (Figure 2).

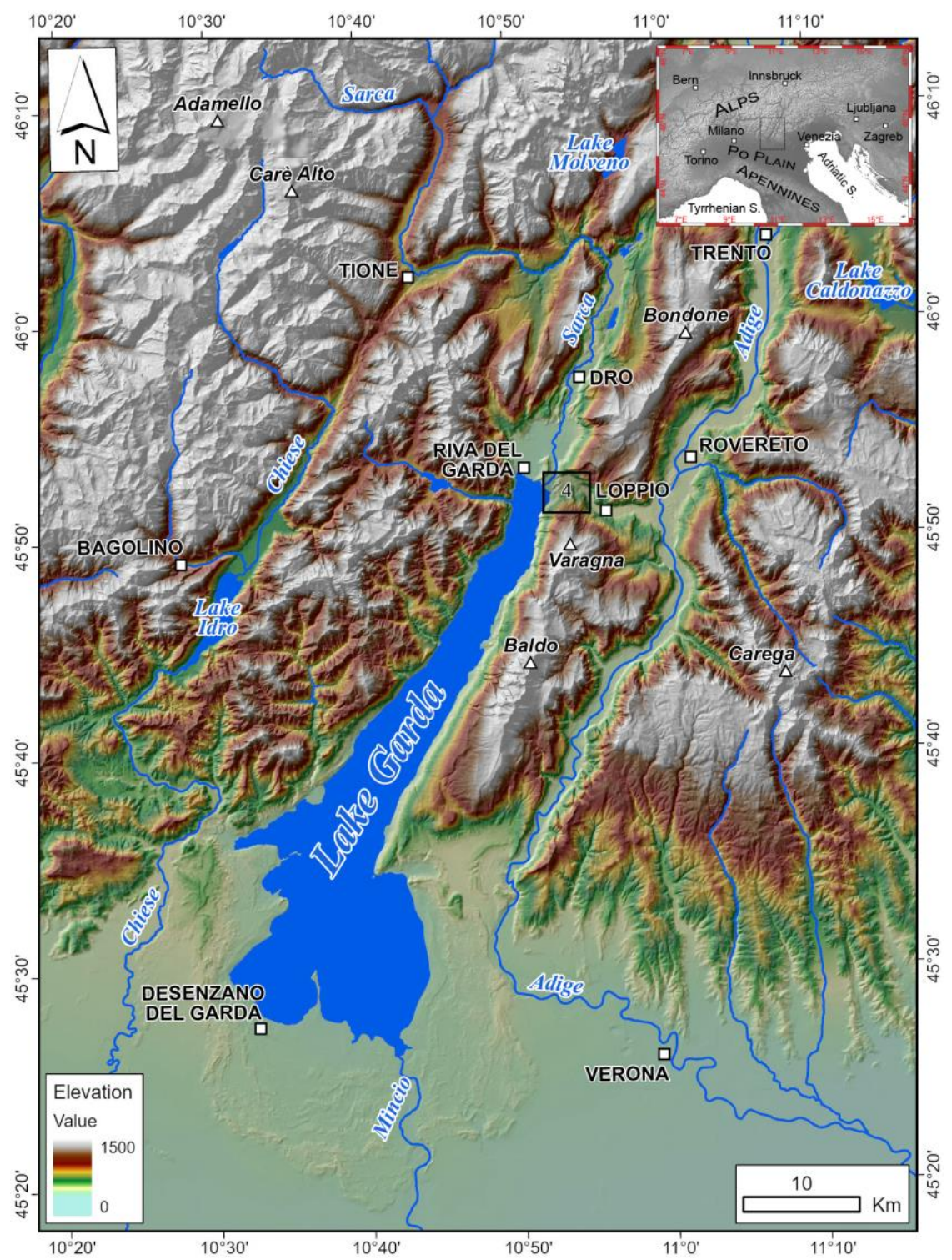

Figure 1. Geographical overview of the Alpine sector where the study area is. The major cities, peaks, rivers and lakes are shown, together with the location of Figure 4. The background was obtained from the Italian SRTM derived digital elevation model ( $25 \mathrm{~m}$ cells). 


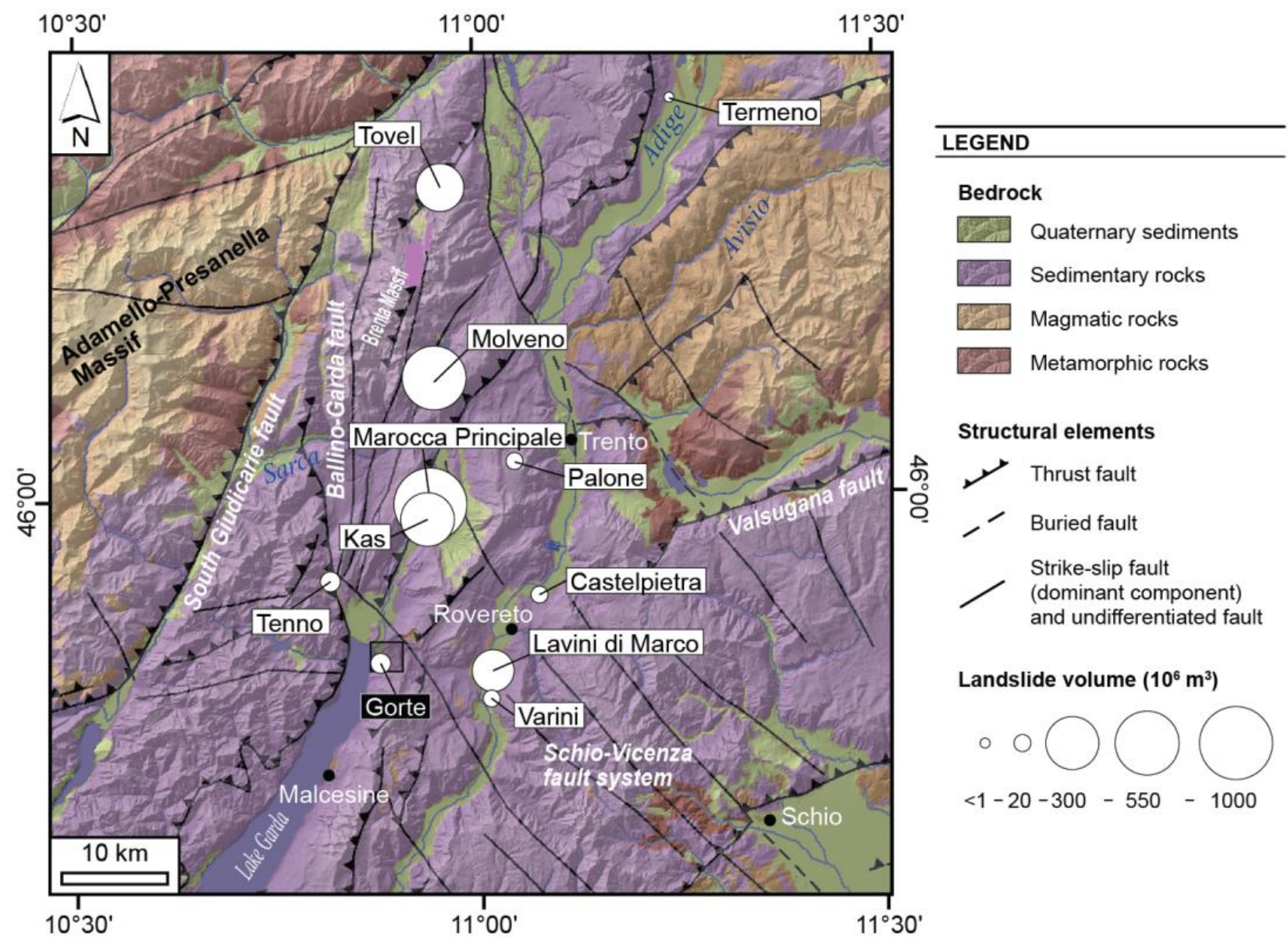

Figure 2. Simplified geological map of the Sarca and Adige Valleys (data from the Geological Survey of Trento, CARG project database) with the locations of the major landslides that have occurred in the area. Circle sizes are proportional to landslide volume (modified from [26]; Elsevier used with permission). The Tovel deposits are grouped in a single circle, despite the fact they are due to many events, with an estimated total volume of $300 \mathrm{Mm}^{3}$ [27]. The Gorte rock avalanche is marked in black. The gray square corresponds to the location of Figure 4.

Our study is focused on the largest deposit, the Gorte rock avalanche that detached from the Paternoster bedrock niche, and the deposit located at the foot of the Spiaz de Navesele-Salto della Capra release area (Figure 3). The aim of our study was to clarify whether the Gorte deposits were formed during a single event or during several events, as proposed by $[28,29]$. We used a multi-method approach combining field surveys supported by remote imagery, cosmogenic ${ }^{36} \mathrm{Cl}$ exposure dating and numerical runout modeling to reconstruct the large slope failures and the emplacement dynamics. Our new data can be compared with nearby isotopically dated deposits, for example, the Marocche di Dro [16], Lavini di Marco [30], Varini [31] and Molveno [12] rock avalanches (Figure 2), which allows an assessment of the most important preconditioning factors and possible triggers in a regional context. The numerical model provides insights into the dynamics of the rock avalanche, the characteristics of the path material and the runout behavior. Thus, this multi-method approach can provide a more complete picture about the landslide forcing factors in this part of the Alps and the possible resulting hazard. 


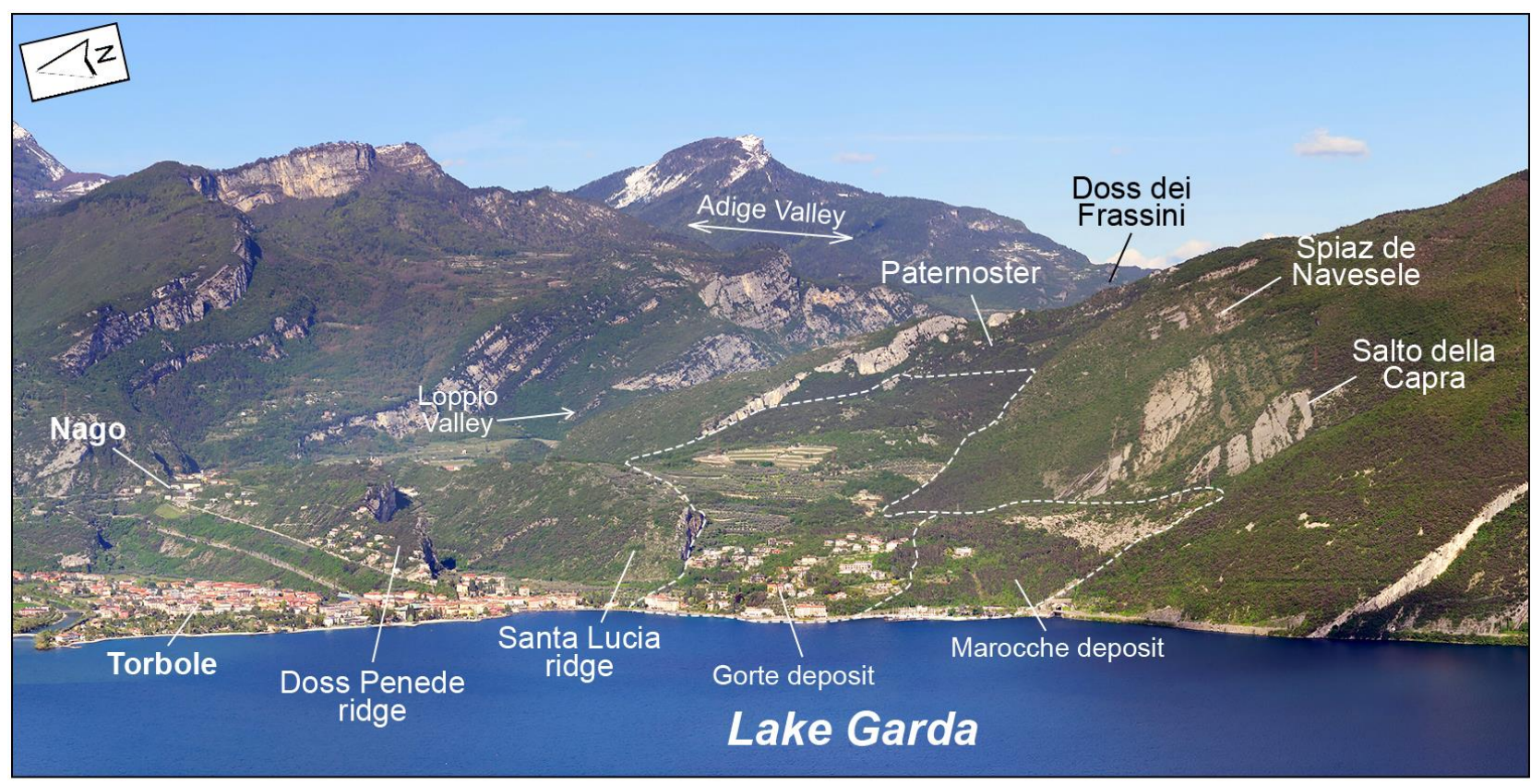

Figure 3. Overview of the landslides of Gorte (on the left) and Marocche (on the right). The latter is due to the visible sliding planes of the Spiaz de Navesele and Salto della Capra. Mouth of the Sarca River seen on the far left of the image. Photo taken from the western side of Lake Garda (photo courtesy of Dr. Matteo Visintainer).

\section{Setting and Previous Work}

\subsection{Geographical Setting}

The study site is located within the NNE-SSW-oriented Lake Garda valley. This valley is linked to the tectonic evolution of the Giudicarie fault [32,33], while its depth is related to the Messinian sea level drop [34-36]. Lake Garda and the lower Sarca Valley are affected by present-day tectonic deformation $[19,37,38]$, and earthquakes with an equivalent magnitude of $M_{e}=5$ are common in the region [39]. These events are correlated with earthquaketriggered landslides on the lake shores and in the lake, as indicated by two seismoturbiditehomogenite beds (undated) that may be related to historic earthquakes [40].

Lake Garda is hosted within an asymmetric syncline. The eastern flanks are $\mathrm{W}$-dipping parallel to the bedding and prone to sliding, while the western ones are steep and cut across the bedding orientation, giving origin to rockfalls [28]. The high topographic gradients of the eastern monoclinal shores and the western rocky cliff ranging in altitude from 100 to $>2000 \mathrm{~m}$ a.s.l. favor slope failure [41] (Figure 1). The presence of numerous landslide scarps within the Mesozoic limestones around Lake Garda demonstrates that the surrounding slopes and lake shore must have suffered dangerous events in the past, including tsunamis, and could be sensitive to new events of the same type. The vulnerability of the slopes to failure is shown by the recent event (2 January 2021) at the locality of Tempesta on the eastern lake shore (http:/ / www.protezionecivile.tn.it/territorio/primop_territorio/ pagina211.html (accessed on 17 September 2021)).

North of the study area, the valley of Loppio connects the Adige Valley to the east and the Sarca Valley that opens to Lake Garda. The terminal tract of the Loppio Valley coincides with the Nago plain ( $230 \mathrm{~m}$ a.s.l.) and is separated from the Sarca Valley by the rocky ridges of Santa Lucia and Doss Penede (Figures 3 and 4). The area of the present Nago alluvial plain is a basin receiving sediment from the adjacent slopes and from the Passo San Giovanni area drainages to the east. Minor gravitational events likely blocked the outlets to the north and west, allowing the accumulation of alluvial and lacustrine sediments. Geophysical surveys in the Passo San Giovanni area suggest a fill composed of $120 \mathrm{~m}$ of fine-grained sediments [42]. 


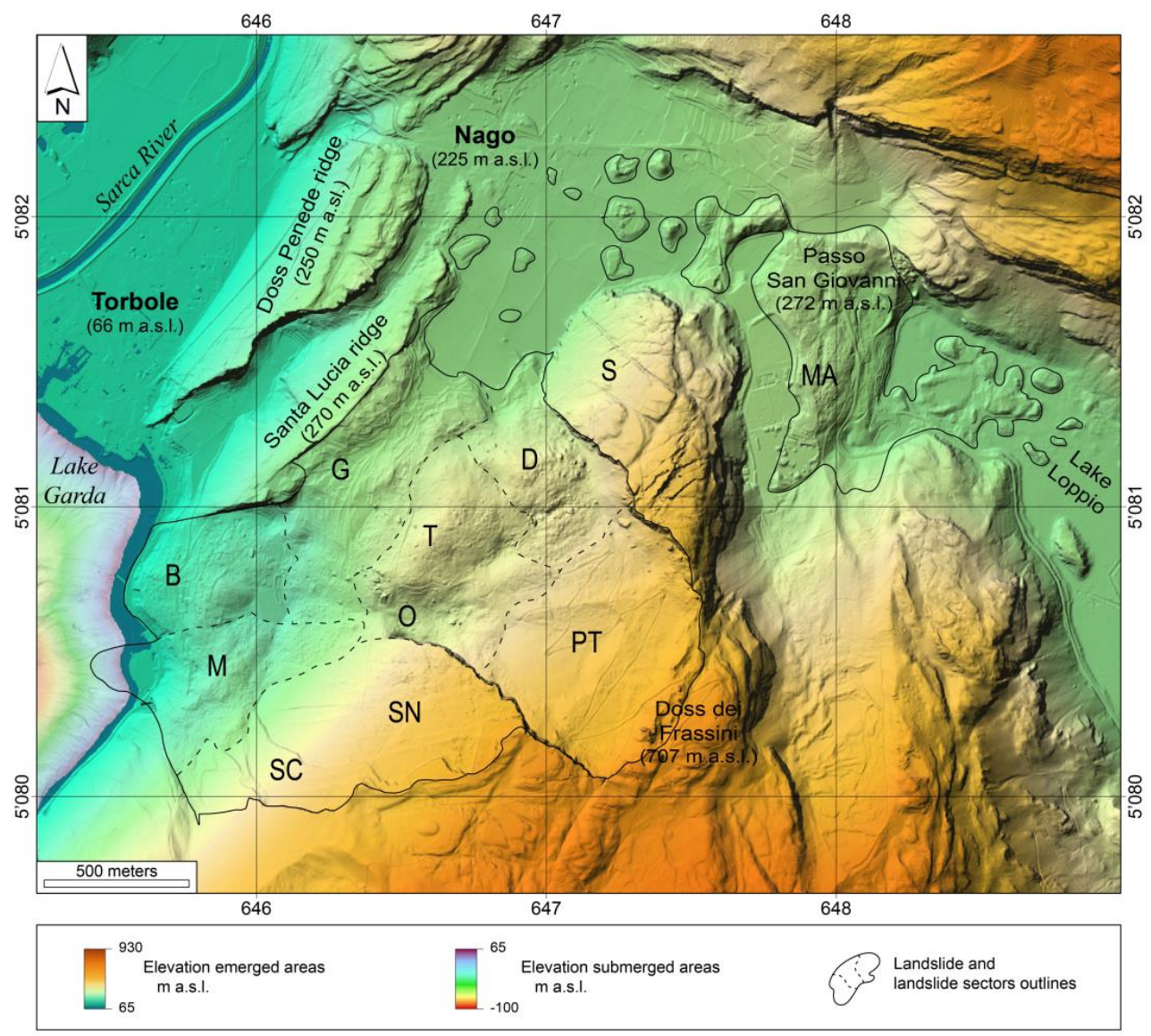

Figure 4. Shaded relief map of the study area with the most important toponyms, i.e., names, of the different areas mentioned in the text. B: Busatte, D: Daine, G: Gorte, M: Marocche, MA: Mala, O: Oltrezengol Valley, PT: Paternoster, S: Segron, SC: Salto della Capra, SN: Spiaz de Navesele, T: Tiro a Volo.

Several distinctive rock avalanche deposits are present at the junction between the paleovalley connecting the Loppio area with Lake Garda (Figure 4). According to [28], these include the following:

- The Gorte deposits, studied herein, with a release area along the western Doss dei Frassini slope (Paternoster);

- "Marocche" (this term is described more in detail below) deposits from the Spiaz de Navesele-Salto della Capra release areas which are also studied in the present work and will be referred to as Spiaz de Navesele;

- Tomas (conical hillocks) around the town of Nago interpreted to relate to the Segron release area;

- Deposits known as Mala located at Passo San Giovanni and interpreted to be sourced from the northern slope of Doss dei Frassini.

These deposits rest, at least partially, upon alluvial and/or lacustrine sediments accumulated inside the paleovalley of the Nago area and are, in turn, covered, to some extent, by the alluvial sediments forming the present-day Nago plain.

The prominent release areas in the surrounding bedrock slopes, for example, at Paternoster, and the blocky deposits in the Nago-Torbole region have been recognized and mapped for more than a century. In his Rovereto-Riva map (scale 1:75,000), Vacek [43] did not represent any landslide in the area. On the contrary, in his map, Habbe [44] drew three landslide deposits coming from Doss dei Frassini, by adding the deposit named here as Marocche located to the south of the Gorte deposits. In the Nago-Torbole area, Perna [28] mapped eight different landslide deposits, five of which correspond to the Daine, Tiro a Volo, Gorte, 
Busatte and Marocche deposits as shown in Figure 4. Note that we use the term "Gorte" to refer to the whole of these deposits, excluding Marocche to the south.

Several names have been used to indicate the landslide deposits from the Doss dei Frassini western slope by previous authors. In Trentino, the word "Marocca" is used to indicate a chaotic mass of loose blocks. The word derives from the Paleo-European word mar (or kar), which means rock [28]. A "Marocca" is therefore a blocky landslide deposit. Based on observations of karst structures and the geomorphology of the deposits, [28,29] estimated that the main landslide event from the Doss dei Frassini western slope (Paternoster release area) occurred 10,000-5000 years ago, perhaps as three different events. In these estimations, the first event led to the formation of the Gorte and Busatte deposits (Figure 4), while the second led to the formation of the Daine and Tiro a Volo deposits. The third event involved only the walls delimiting the Paternoster release area, and the Daine and Oltrezengol Valley area. The volume of the total Gorte landslide release area (Paternoster) was estimated by [28] to be about $76 \mathrm{Mm}^{3}$, while for the deposits, he estimated a volume of $98 \mathrm{Mm}^{3}$. The landslide of Spiaz de Navesele-Salto della Capra is more recent as the blocky deposits overlie the deposit of Gorte. A volume of the bedrock released in the Spiaz de Navesele landslide was estimated at $2.5 \mathrm{Mm}^{3}$, while the deposit volume ("Marocche" in the topographic map, Figure 4) was estimated at around $3.2 \mathrm{Mm}^{3}$ [28].

\subsection{Stratigraphic and Tectonic Setting}

The Nago-Torbole landslide area is located 5-10 km to the east of the Ballino fault, which itself is connected with the Giudicarie fault (Figure 2). This fault divides the Lombardian basin, located to the west formed by deep-water Jurassic sediments, from the Trento carbonate platform, located to the east of the Ballino fault formed by shallow-water sediments. The area of Nago-Torbole is therefore located inside the Trento carbonate platform, which consists of limestones deposited during the Early and Middle Jurassic (Figure 5) [41,45].

At the base of the stratigraphy, there is the Rotzo Formation (RTZ), followed by the Massone Oolite Formation (OOM), which closes the Calcari Grigi Group ("Gray Limestones"). Above the Calcari Grigi, there are the Tofino Formation (TOF), particularly the member of Bocchetta Slavazi, and the San Vigilio Oolite Formation (OSV) on the southern boundary [41]. On the basis of field observations and thin sections, the RTZ Formation is a bioclastic peloidal gray micritic limestone (mudstone, in the samples identified as packstone) with mollusca fragments (e.g., bivalves, gastropods) and foraminifera in layers varying from some decimeters up to decameters, with dark marl interlayers rich in coal or black shales and oolitic calcarenites. The OOM Formation is a light gray to white oolitic limestone in thick layers $(30-60 \mathrm{~cm})$, locally cross-laminated, classified as grainstone including bioclasts such as calcispondes, bivalves, crinoids and echinoderm fragments. The TOF Formation is a micritic dark gray limestone (packstone to grainstone) with sponge spicules and radiolaria in medium-thin beds, brachiopods, crinoids and pelagic lamellibranchia. The OSV Formation is a yellowish crinoid oolitic limestone, in thick layers that are poorly stratified, sometimes cross-bedded. The OSV can be distinguished from the OOM because of the smaller oolites.

The tectonic setting of the Nago-Torbole area can be traced back to the post-collisional evolution of the Alps characterized by compression events of the Neogene [41]. However, some N-S-oriented morphological lineaments or fractures related to the Liassic faults, i.e., the Ballino line, are still well recognizable. The Valsugana event, which took place in the Serravalian-Tortonian (13-8 Ma), led to the formation of the NNE-SSW (NE-SW)trending Giudicarie fault system [46]. The second fault system present in this area is the Schio-Vicenza, composed of subvertical NW-SE faults, linked to the Schio-Vicenza event which occurred during the Messinian-Pliocene (7-3 Ma) [46]. The Giudicarie and Schio-Vicenza have determined the tectonic setting of the area between Lake Loppio and the Sarca Valley, creating a system of lineaments, fractures and discontinuities that, in part, border and, in part, cross-cut the Nago-Torbole landslide area (Figure 2). 


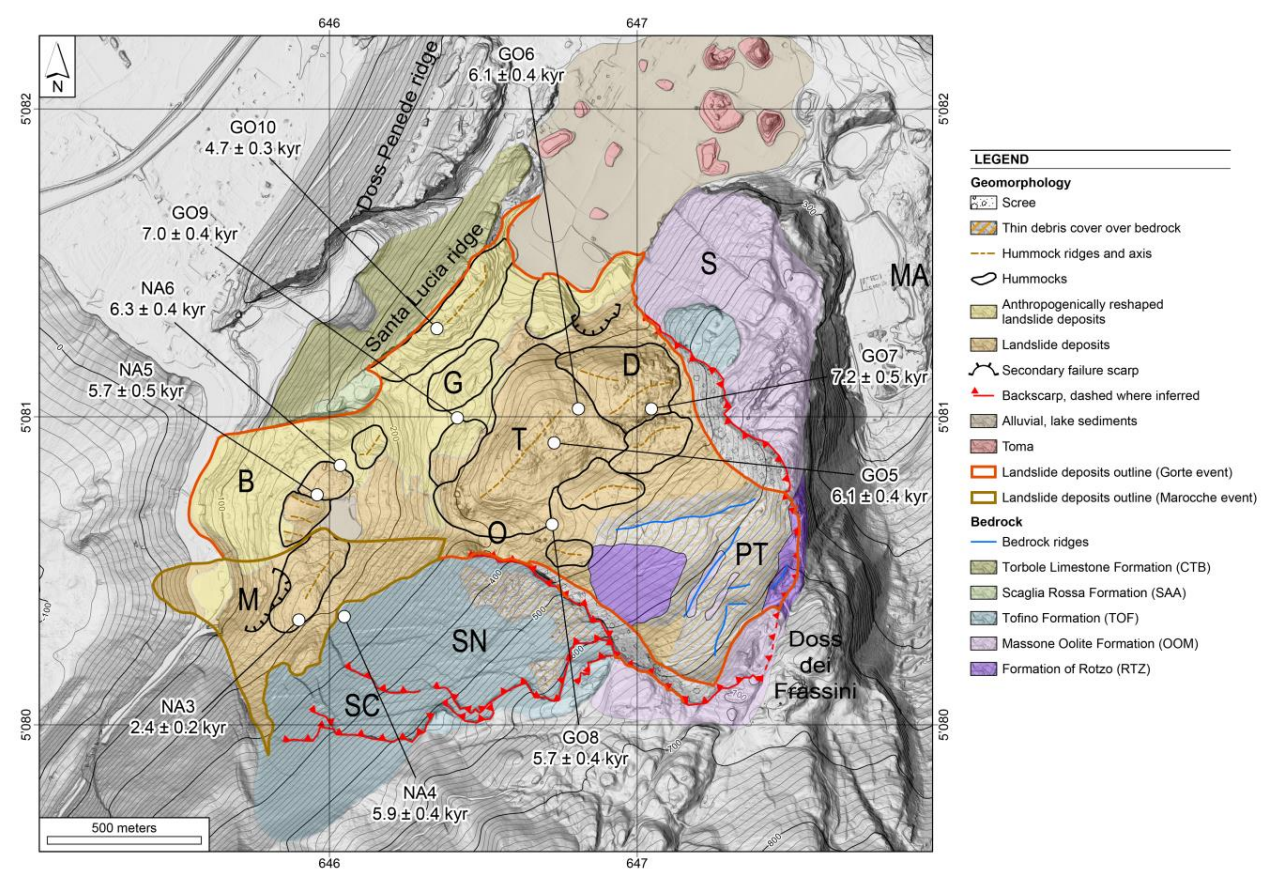

Figure 5. Geomorphological map of the study area. Boulders dated with ${ }^{36} \mathrm{Cl}$ and the calculated exposure ages are shown (Table 1). Samples NA4 (bedrock) and NA3 are from the Spiaz de Navesele event, and all others are boulders in the Gorte landslide deposits. B: Busatte, D: Daine, G: Gorte, M: Marocche, MA: Mala, O: Oltrezengol Valley, PT: Paternoster, S: Segron, SC: Salto della Capra, SN: Spiaz de Navesele, T: Tiro a Volo.

\section{Methods}

\subsection{Field Survey and Remote Sensing}

The field survey was completed using printed maps, supported by tablets with GIS Pro and Fieldmove apps. A project was created with ArcGIS Pro (ESRI) and integrated with LiDAR, a digital terrain model (DTM) and a digital surface model (DSM), with a resolution of $1 \times 1 \mathrm{~m}$ [47], and high-resolution orthophotos acquired over different years. The data were analyzed in ArcGIS Pro to create maps such as slope, aspect and multidirectional hillshades (Raster Functions toolbox). In addition, topographic maps [47], the geological map [41] and the natural hazard map [48] were georeferenced and integrated. Furthermore, a bathymetric survey of Lake Garda (Torbole area) carried out in 2019 by the Italian Navy in collaboration with Cattolica University was integrated into the available maps. The hillshade map was created with the DTMs provided by Trento Province and the Italian Navy.

During fieldwork, we collected samples from the deposits and the release areas to investigate the stratigraphic characteristics and to confirm the provenance of the landslide boulders. We used the GIS Pro application to record points, lines and polygons, which we then exported in different formats (e.g., shapefile, or KML/GPX) and opened with software such as ArcGIS and Google Earth. Discontinuities (i.e., bedding, joint sets, faults, cleavage) were measured in the field and similarly located on the DEM. These data were analyzed using the cluster analysis tool of the Dips software using Fischer's density distribution. The position of the entered data was recorded through the GPS integrated in the device; the accuracy is on the order of a few meters.

We integrated all these data and further field observations to create a geomorphological map. This provided the basis for the analysis and interpretation of landforms and for the runout analysis. The DEM was further processed by drawing identified lineaments, which were further processed using the "Linear Directional Mean" tool in ArcGIS Pro to calculate the strike direction. These data were displayed as structural plots using the software Dips. Geomechanical measurements on Jurassic limestones conducted by the 
Province of Trento laboratory were taken into consideration for analyzing the friction coefficient of the lithologies involved in the landslides to determine the predisposition to downward movement [42].

\subsection{Cosmogenic ${ }^{36} \mathrm{Cl}$ Exposure Dating}

Sixteen samples were taken for ${ }^{36} \mathrm{Cl}$ dating from sites all across the Gorte and Spiaz de Navesele landslide deposits. Ten boulders and six bedrock detachment surfaces were sampled with a battery-operated saw and hammer and chisel (locations shown in Figure 5). Boulders were sampled following the guidelines described in [49]: selected boulders were large in size ( $>2 \mathrm{~m}$ in height) to avoid displacement after the landslide, as massive as possible, and sampled from a surface not parallel to the bedding, in order to avoid pre-exposure (cf. [30]). The lithologies of all the samples are shown in Figure S1 of the Supplementary Material. Samples GO5-GO8 and GO10 were composed of OOM, while the GO9 and NA3-NA6 samples were composed of TOF.

Ten samples, nine from boulders in the deposits and one from the bedrock at the Spiaz de Navesele sliding plane (NA4), were prepared and measured with accelerator mass spectrometry (AMS) at the Laboratory of Ion Beam Physics, ETH Zurich (Table 1). Rock samples were crushed and sieved to $<0.4 \mathrm{~mm}$. After preliminary treatment with water and weak $\mathrm{HNO}_{3}$, rock samples were dissolved with $\mathrm{HNO}_{3}$ after addition of ${ }^{35} \mathrm{Cl}$ carrier following the procedures for the isotope dilution methodology presented in [50]. ${ }^{36} \mathrm{Cl} / \mathrm{Cl}$ ratios were measured with the Ion Beam Physics ETH 6 MV TANDEM AMS system relative to the internal $\mathrm{K} 382 / 4 \mathrm{~N}^{36} \mathrm{Cl} / \mathrm{Cl}$ standard $\left(17.36 \times 10^{-12}\right)$ and corrected for a procedural laboratory blank of $(1.94 \pm 0.34) \times 10^{-15}$ (Table 1) [51-53]. Major and trace elements were measured on aliquots of sample material with ICP-MS at Actlabs (Ontario, Canada) (Table 2).

Table 1. Sample name, AMS-measured ${ }^{36} \mathrm{Cl}$ concentrations and calculated apparent exposure ages (Figure 5).

\begin{tabular}{|c|c|c|c|c|c|c|c|c|c|c|c|}
\hline \multirow{2}{*}{$\begin{array}{c}\text { Sample } \\
\text { GO5 }\end{array}$} & \multirow{2}{*}{$\begin{array}{c}\begin{array}{c}\text { Latitude } \\
\text { North }\left(^{\circ}\right)\end{array} \\
45.8662\end{array}$} & \multirow{2}{*}{$\begin{array}{c}\begin{array}{c}\text { Longitude } \\
\text { East }\left(^{\circ}\right)\end{array} \\
10.8903\end{array}$} & \multirow{2}{*}{$\begin{array}{c}\begin{array}{c}\text { Elevation } \\
\text { (m a.s.1.) }\end{array} \\
370\end{array}$} & \multirow{2}{*}{$\begin{array}{c}\text { Thickness } \\
\text { (cm) }\end{array}$} & \multirow{2}{*}{$\begin{array}{c}\begin{array}{c}\text { Topographic } \\
\text { Shielding }\end{array} \\
0.956\end{array}$} & \multicolumn{3}{|c|}{$\begin{array}{l}{ }^{36} \mathrm{Cl} \text { Concentration }{ }^{1} \\
\left(10^{6} \text { atoms/gram }{ }_{\text {rock }}\right)\end{array}$} & \multicolumn{3}{|c|}{$\begin{array}{c}\text { Apparent } \\
\text { Exposure Age (ka) }\end{array}$} \\
\hline & & & & & & 0.168 & \pm & 0.009 & 6.05 & \pm & 0.37 \\
\hline GO6 & 45.8672 & 10.8914 & 368 & 2 & 0.992 & 0.173 & \pm & 0.009 & 6.10 & \pm & 0.37 \\
\hline GO7 & 45.8670 & 10.8942 & 387 & 1 & 0.989 & 0.208 & \pm & 0.011 & 7.17 & \pm & 0.46 \\
\hline GO8 & 45.8636 & 10.8903 & 355 & 1 & 0.967 & 0.157 & \pm & 0.010 & 5.66 & \pm & 0.40 \\
\hline GO9 & 45.8670 & 10.8863 & 277 & 2 & 0.933 & 0.171 & \pm & 0.008 & 6.96 & \pm & 0.41 \\
\hline GO10 & 45.8696 & 10.8856 & 274 & 2 & 0.958 & 0.122 & \pm & 0.007 & 4.73 & \pm & 0.32 \\
\hline NA3 & 45.8613 & 10.8796 & 196 & 2.5 & 0.969 & 0.057 & \pm & 0.005 & 2.42 & \pm & 0.24 \\
\hline NA4 & 45.8613 & 10.8812 & 205 & 2 & 0.968 & 0.144 & \pm & 0.008 & 5.93 & \pm & 0.37 \\
\hline NA5 & 45.8648 & 10.8805 & 172 & 2 & 0.978 & 0.131 & \pm & 0.011 & 5.65 & \pm & 0.49 \\
\hline NA6 & 45.8657 & 10.8815 & 165 & 2 & 0.968 & 0.146 & \pm & 0.008 & 6.29 & \pm & 0.40 \\
\hline
\end{tabular}

${ }^{1}$ Measured against standard K382/4N $(17.36 \pm 0.35) \times 10^{-12}[51,52]$.

We used an in-house MATLAB code to calculate ${ }^{36} \mathrm{Cl}$ exposure ages. The code is based on the constants and equations presented in [54] (and references therein) and includes production through all pathways. Production rates were calculated individually for each sample based on the measured elemental concentrations (Table 2). We used the spallation production rate of $48.8 \pm 3.4{ }^{36} \mathrm{Cl}$ atoms $\left(\mathrm{g}_{\mathrm{Ca}}\right)^{-1} \mathrm{a}^{-1}$ [55]. Treatment of muon production is described in detail in [54] and [56] and amounted to $9.6 \%$ at the rock surface. The contribution of neutron capture to ${ }^{35} \mathrm{Cl}$-to- $-{ }^{36} \mathrm{Cl}$ production was calculated based on a value of $760 \pm 150$ neutrons (gair) ${ }^{-1} \mathrm{a}^{-1}$ [54]. These values are in excellent agreement with the recently published production rates of [57]. Topographic shielding correction was calculated with the MATLAB skyline function (http:/ / stoneage.ice-d.org/math/skyline/ skyline_in.html (accessed on 17 September 2021) (Balco 2018)). Production rates were scaled to the sample locations using the time-dependent scaling model (Lm) [58]. No correction was conducted for karst weathering of the boulder surfaces. Implementing a rate of $5 \mathrm{~mm} \mathrm{ka}^{-1}$ ([59] and references therein) resulted in $\sim 2 \%$ older ages. Final age uncertainties (Table 1 and Figure 5) included both analytical (one sigma) and production rate uncertainties. 
Table 2. Elemental composition of leached samples. $\mathrm{Cl}$ values are from AMS measurements.

\begin{tabular}{|c|c|c|c|c|c|c|c|c|c|c|c|c|c|c|c|c|c|}
\hline Sample & $\begin{array}{c}\mathrm{Al}_{2} \mathrm{O}_{3} \\
(\%)\end{array}$ & $\begin{array}{c}\mathrm{CaO} \\
(\%)\end{array}$ & $\begin{array}{c}\mathrm{Fe}_{2} \mathrm{O}_{3} \\
(\%)\end{array}$ & $\begin{array}{c}\mathrm{K}_{2} \mathrm{O} \\
(\%)\end{array}$ & $\begin{array}{c}\mathrm{MgO} \\
(\%)\end{array}$ & $\begin{array}{c}\mathrm{MnO} \\
(\%)\end{array}$ & $\underset{(\%)}{\mathrm{Na}_{2} \mathrm{O}}$ & $\begin{array}{c}\mathrm{P}_{2} \mathrm{O}_{5} \\
(\%)\end{array}$ & $\begin{array}{c}\mathrm{SiO}_{2} \\
(\%)\end{array}$ & $\begin{array}{c}\mathrm{TiO}_{2} \\
(\%)\end{array}$ & $\begin{array}{l}\text { Sm } \\
(\mathrm{ppm})\end{array}$ & $\begin{array}{l}\text { Gd } \\
(p p m)\end{array}$ & $\underset{(\mathrm{ppm})}{\mathrm{U}}$ & $\begin{array}{c}\text { Th } \\
\text { (ppm) }\end{array}$ & & $\begin{array}{c}\mathrm{Cl} \\
(\mathrm{ppm})\end{array}$ & \\
\hline GO5 & 0.1 & 54.94 & 0.05 & 0.03 & 0.39 & 0.006 & 0.03 & 0.02 & 0.28 & 0.003 & 0.1 & 0.1 & 0.6 & $<0.1$ & 13.5 & \pm & 0.1 \\
\hline GO6 & 0.07 & 54.32 & 0.05 & 0.01 & 0.39 & 0.007 & 0.03 & 0.01 & 0.22 & 0.001 & $<0.1$ & 0.1 & 0.7 & $<0.1$ & 11.1 & \pm & 0.1 \\
\hline GO7 & 0.08 & 54.44 & 0.04 & 0.02 & 0.37 & 0.006 & 0.03 & $<0.01$ & 0.21 & 0.001 & 0.1 & 0.1 & 0.6 & $<0.1$ & 12.0 & \pm & 0.1 \\
\hline GO8 & 0.11 & 54.62 & 0.06 & 0.03 & 0.41 & 0.006 & 0.03 & 0.02 & 0.28 & 0.003 & 0.1 & 0.2 & 0.6 & $<0.1$ & 13.4 & \pm & 0.1 \\
\hline GO9 & 0.18 & 53.78 & 0.17 & 0.05 & 0.65 & 0.018 & 0.03 & 0.01 & 0.66 & 0.008 & 1.3 & 1.6 & 1.5 & 0.3 & 14.2 & \pm & 0.1 \\
\hline GO10 & 0.11 & 54.74 & 0.05 & 0.03 & 0.48 & 0.005 & 0.03 & 0.02 & 0.37 & 0.003 & 0.1 & 0.2 & 0.5 & $<0.1$ & 15.4 & \pm & 0.1 \\
\hline NA3 & 0.51 & 52.59 & 0.29 & 0.12 & 1.27 & 0.020 & 0.04 & 0.04 & 1.87 & 0.028 & 1.2 & 1.5 & 0.3 & 0.6 & 13.8 & \pm & 0.1 \\
\hline NA4 & 0.09 & 54.66 & 0.06 & 0.02 & 0.42 & 0.008 & 0.03 & $<0.01$ & 0.32 & 0.002 & 0.2 & 0.2 & 0.6 & $<0.1$ & 13.9 & \pm & 0.1 \\
\hline NA5 & 0.26 & 52.48 & 0.14 & 0.08 & 1.51 & 0.023 & 0.03 & 0.02 & 0.76 & 0.013 & 0.9 & 1.1 & 0.1 & 0.3 & 16.5 & \pm & 0.1 \\
\hline NA6 & 0.18 & 54.04 & 0.16 & 0.05 & 0.42 & 0.015 & 0.03 & 0.03 & 0.76 & 0.008 & 1 & 1.3 & 0.2 & 0.3 & 15.2 & \pm & 0.1 \\
\hline
\end{tabular}

\subsection{Reconstruction of Pre-Failure Topography and Volume Estimation}

The topography of the valley prior to failure and the volume of the rock avalanche are key elements in analyzing the dynamic behavior of a landslide, and they are also an input for magnitude frequency analysis [60,61]. Both the initial volume of failed material (hereinafter referred to as "source" volume) and the deposit volume were estimated by reconstructing the pre-failure topography, and then differencing it from the present-day topography, accounting for any deposits that remain on the source zone rupture surface. It should be noted that the volume of deposits is expected to be approximately $25 \%$ higher than the source volume, as fragmentation and bulking lead to a volume increase [62]. The reconstruction was based on a newly created, present-day contour map obtained by combining a bathymetric survey of Lake Garda with the available LiDAR data [47]. We then integrated information from the geomorphological analysis and cosmogenic dating to interpret the pre-failure valley morphology, as further described in the Results section below.

\subsection{Runout Modeling}

We back-analyzed the dynamics of the Gorte rock avalanche using the semi-empirical runout model Dan3D-Flex [63]. This allowed us to test the plausibility of our reconstructed topography and our proposed failure scenario. Additionally, the back-analyzed basal shear strengths can be compared to values obtained at other rock avalanches, allowing us to contextualize the mobility of the Gorte rock avalanche.

Dan3D-Flex initially treats the failed mass as a "flexible block", which translates and rotates over the reconstructed topography. At a user-specified time, the mass fluidizes and is simulated as a frictional fluid whose behavior is governed by internal and basal rheologies $[63,64]$. In this study, the frictional rheology was used in the source area, where the rock avalanche moves over the rupture plane, and the Voellmy rheology was used for the path, consistent with the approach of [7]. These two rheologies are described in detail in [65] and will only be briefly descried here. The frictional rheology is a one-parameter rheology, and basal resistance is the product of bed-normal effective stress and the tangent of the friction angle, which is the calibrated parameter. The two-parameter Voellmy rheology combines a frictional term, proportional to a calibrated friction coefficient (f), with a velocity-dependent term, which is governed by a calibrated turbulence coefficient $(\xi)$. The reconstructed pre-failure topographic surface is also a key input for runout modeling, and in the present work, we smoothed the DEM three times using a Gaussian low-pass filter, in order to aid the numerical stability.

To calibrate the model, we first performed a trial-and-error analysis to constrain the best-fit source zone friction angle and time spent as a flexible block. For this initial calibration step, the deposit volume in the source zone was the primary constraint used to assess the accuracy of simulations. Following this initial calibration, these values were held constant, and a posterior analysis, described in detail in [66], was used to constrain the two Voellmy parameters. Briefly, a posterior analysis computes the simulated results 
for a wide variety of parameter combinations and quantitatively compares the results to observations of the impact area and deposit volume. The algorithm then assigns the parameters which result in the closest match to field observations as more probable than those that result in a worse fit. In the present work, friction coefficients between 0.17 and 0.45 , with steps of 0.1 , and turbulence coefficients between 100 and $2000 \mathrm{~m} / \mathrm{s}^{2}$, with steps of 100 , were used.

\section{Results}

\subsection{Geomorphology and Age of the Gorte and the Spiaz de Navesele Landslides}

The geomorphological analysis and deposit dating provide the basis for understanding the failure sequence of the two studied landslides and allow us to place these events in a regional context. Based on field relationships, we subdivided the deposits released from the western slope of Doss dei Frassini into the Gorte and the Spiaz de Navesele-Salto della Capra landslides, with the deposits of the latter overlying the former. Deposits of the Gorte landslide stem from the Paternoster release area, while the "Marocche" deposits relate to the Spiaz de Navesele-Salto della Capra source.

We mapped 730 morphological lineaments all over the study area (Figure 6). Discontinuities in the bedrock of the Paternoster and the Spiaz de Navesele-Salto della Capra release areas can be grouped into four different sets.

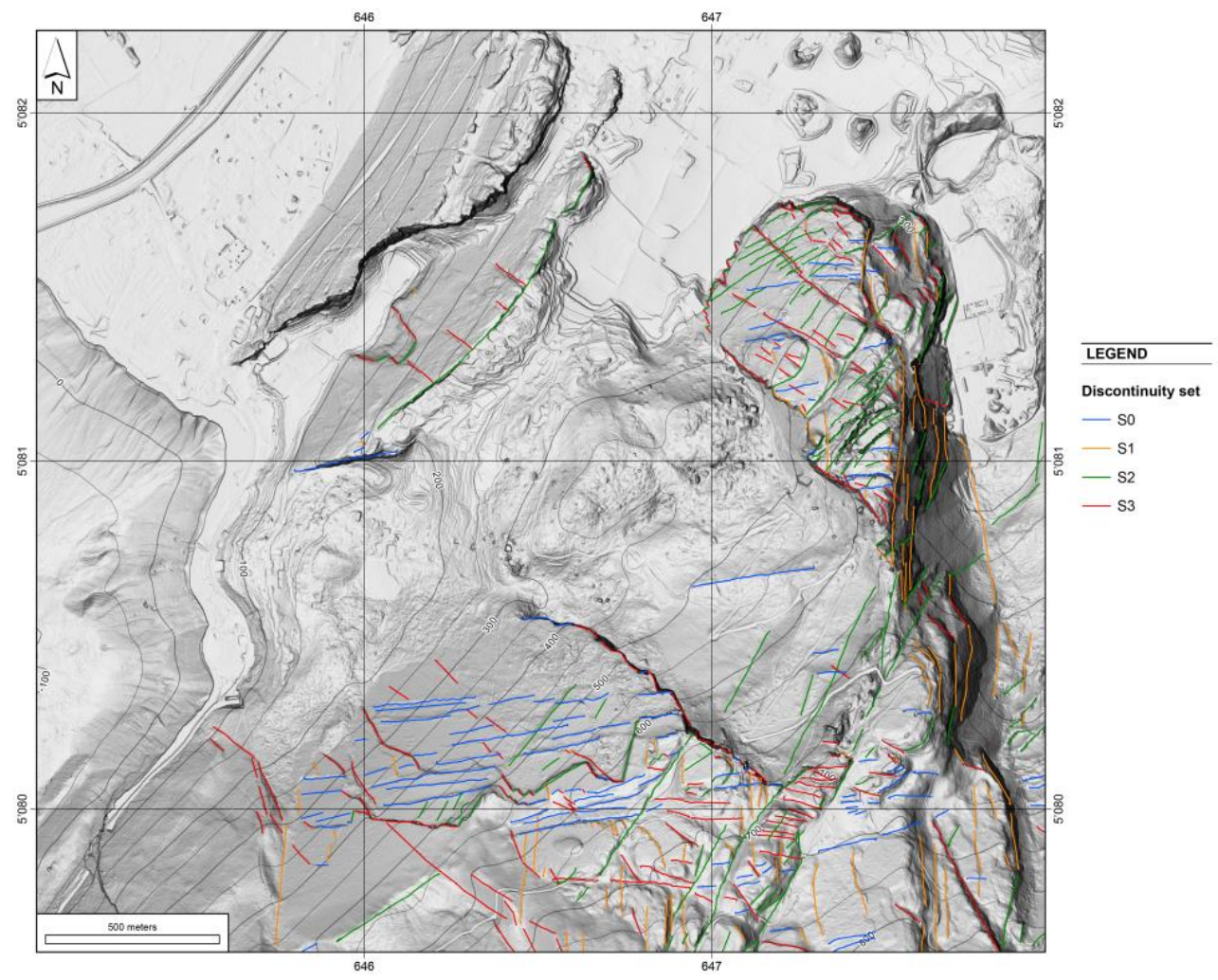

Figure 6. Structural lineaments identified in the study area. The measured discontinuities are grouped into four sets, identified by different colors. Colors of sets correspond to those of Figure 7.

The bedding $\left(\mathrm{S}_{0}\right)$ has an average orientation of $313^{\circ} / 27^{\circ}$ (dip direction/dip angle), with dip angles varying from $20^{\circ}-25^{\circ}$ in the upper part to $25^{\circ}-28^{\circ}$ in the central sector. The other main discontinuities $\left(\mathrm{S}_{1}-\mathrm{S}_{3}\right)$ are subvertical (dip angles $\left.>70^{\circ}\right)$. The $\mathrm{S}_{1}$ set strikes NNW-SSE $\left(072^{\circ} / 71^{\circ}\right)$, with an average dip angle of $71^{\circ} ; S_{2}$ strikes NNE-SSW $\left(112^{\circ} / 74^{\circ}\right)$, with an average dip angle of $74^{\circ} ; \mathrm{S}_{3}$ constitutes the fracture cleavage, is vertical and strikes WNW-ESE $\left(019^{\circ} / 87^{\circ}\right)$ (Figure 7$)$. 

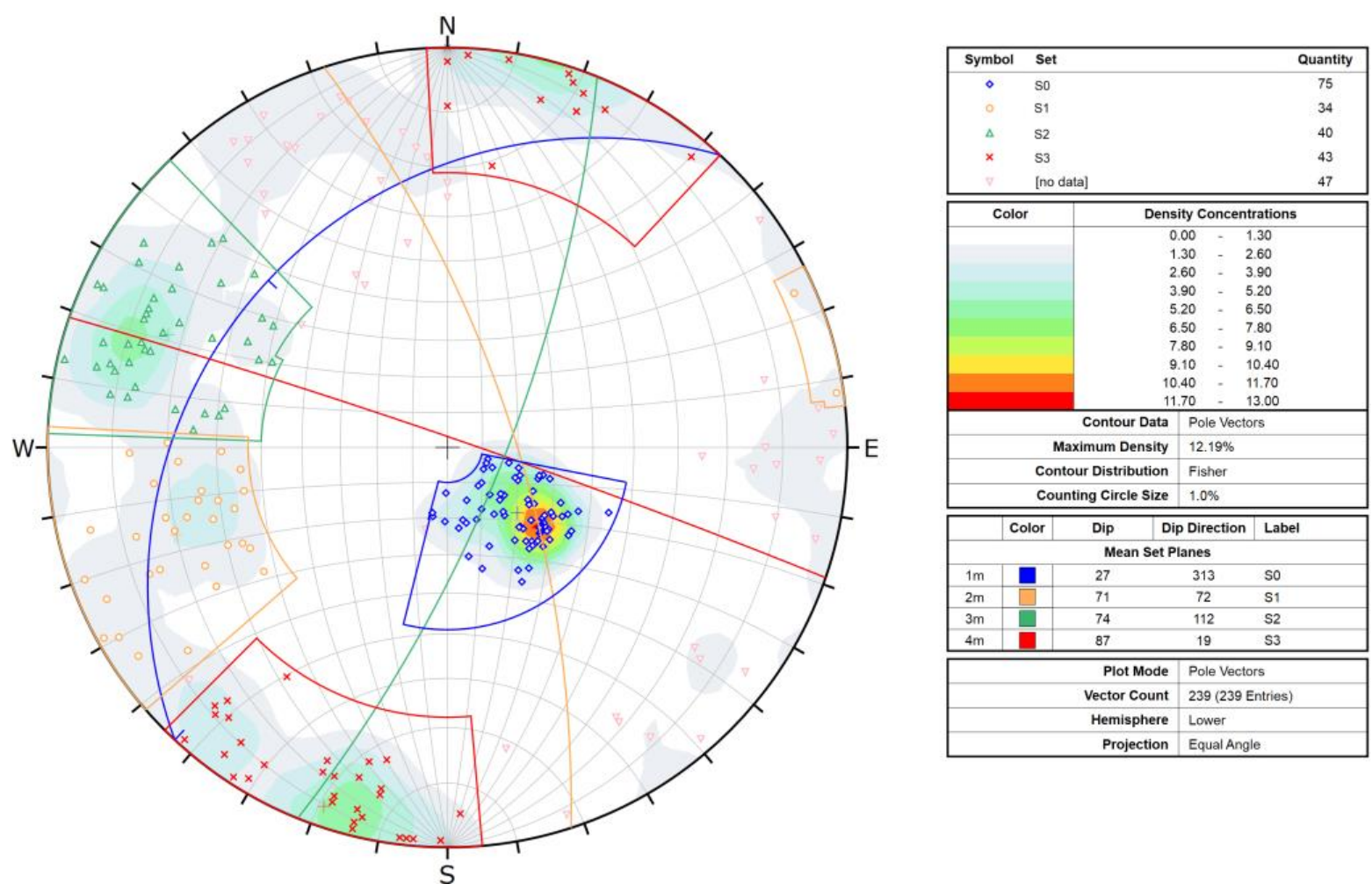

Figure 7. Stereonet of the structural measurements taken in the study area and shown in Figure 6. Colors of sets correspond to those of Figure 6.

\subsubsection{The Gorte Rock Avalanche}

The blocky deposits of the Gorte landslide detached from the Paternoster OOM bedrock (Figure 4). The Paternoster release zone extends from 380 to $700 \mathrm{~m}$ a.s.1. and covers an area of $\sim 0.45 \mathrm{~km}^{2}$. The release area niche is a semi-circular amphitheater that opens to the west. Impressive vertical scarps that are tens of meters high encircle the niche on the northern, eastern and southern sides (Figures 3 and 5). The northern scarp in the Paternoster release area is $~ 800 \mathrm{~m}$ long, 20 to $50 \mathrm{~m}$ high, WNW-ENE-aligned and mainly made of OOM, with a small patch of TOF cropping out in the northernmost part, at the top of the scarp (Figure 8A). The eastern scarp, which corresponds to the backscarp of the rock avalanche, is $\sim 770 \mathrm{~m}$ long and $20-30 \mathrm{~m}$ high. The rock wall is made of RTZ in the northern side and of OOM in the southern side, the boundary between the two formations occurring at an elevation of $\sim 650 \mathrm{~m}$ a.s.l. The southern scarp is $\sim 1200 \mathrm{~m}$ long, 10 to $100 \mathrm{~m}$ high and WNW-ENE-aligned. Here, OOM and RTZ are both present, their boundary occurring at an elevation of $\sim 520 \mathrm{~m}$ a.s.1. In the Paternoster release area, the majority of lineaments are oriented SE-NW or NE-SW, whereas a few E-W lineaments, but no N-S lineaments, are observed. The rocky walls show $S_{1}$ and $S_{2}$ joint sets and a pervasive fracture cleavage foliation. The spacing of the joints (about $50 \mathrm{~cm}$ ) is greater than the spacing of the cleavage (about 5-10 cm).

The sliding plane of the rock avalanche is almost completely covered by a layer of debris up to $5 \mathrm{~m}$ thick, but some patches of bedrock are visible, especially on the southern side (Figure 5). The sliding plane is parallel to the bedding and is made of OOM in the upper part, whilst further west, some scarps cut the stratigraphy, and RTZ is exposed. There are no substantial differences in the orientation of the plane, being $290^{\circ} / 25^{\circ}$ on average $\left(\mathrm{S}_{0}\right)$. Some undulations in the stratigraphy are present, and these form bedrock ridges that interrupt the flatness of the sliding plane. Two major bedrock ridges have been identified in the Paternoster sector: the easternmost (NNW-SSW-aligned) is located at $\sim 500 \mathrm{~m}$ a.s.1. and is made of OOM, and the other is ENE-WSW-aligned and crosses the sliding plane from an elevation of $\sim 500$ to $\sim 400 \mathrm{~m}$ a.s.l. 

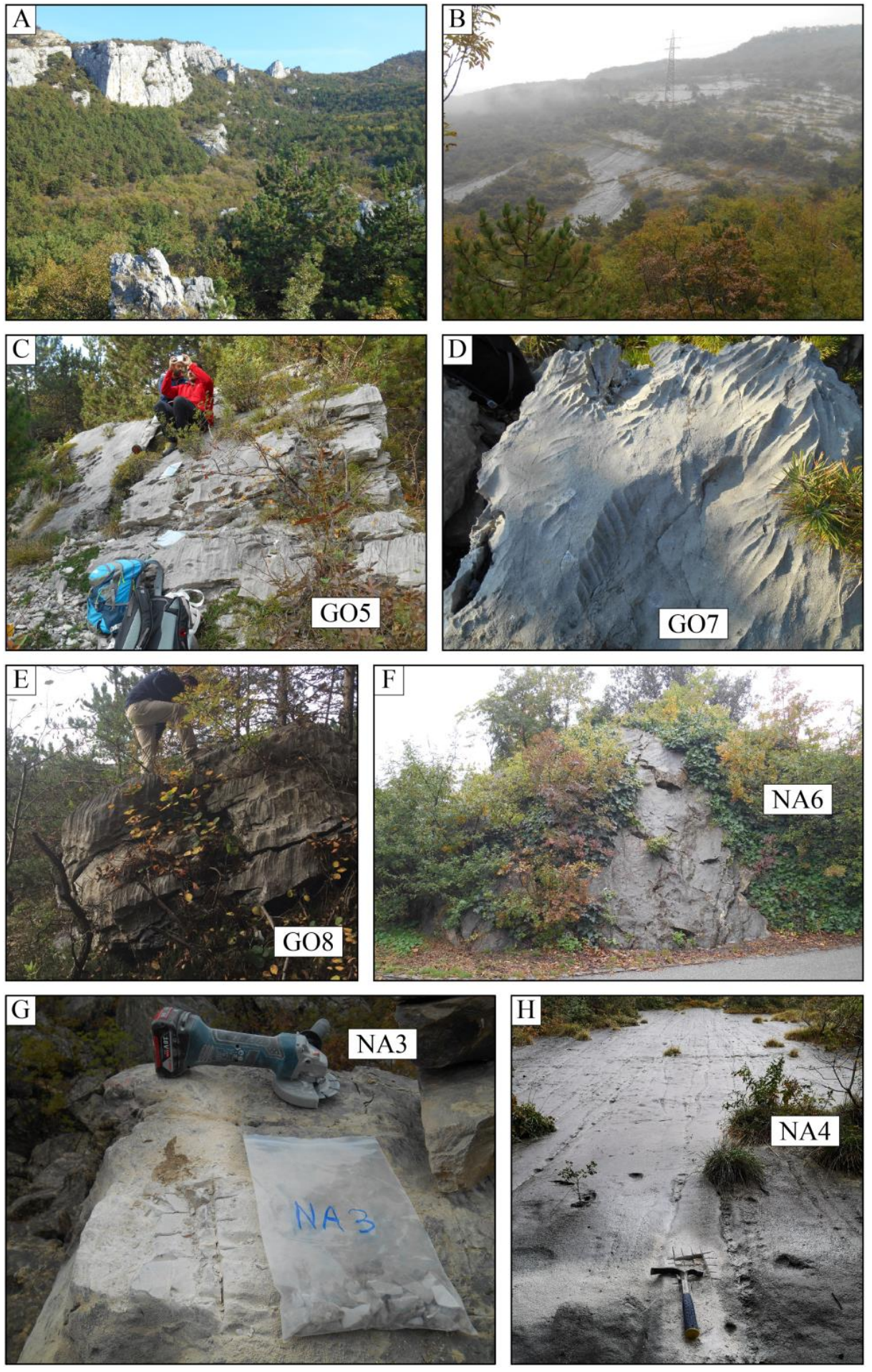

Figure 8. Photos from the study area. (A) The northern flank of the Paternoster release area, taken from the Tiro a Volo area. The wall in the upper left is $80 \mathrm{~m}$ high. Several rock spires are visible in the background. (B) View of the Navesele-Salto della Capra release area. The power line tower is about $30 \mathrm{~m}$ tall. The photos in the second and third lines are of samples from the Gorte rock avalanche deposit. (C) Boulder GO5 (6.1 $\pm 0.4 \mathrm{ka})$. The sample for ${ }^{36} \mathrm{Cl}$ dating was taken from the top surface. (D) Karren on the top sampled surface of boulder GO7 (7.2 $\pm 0.5 \mathrm{ka})$. (E) Boulder GO8 (5.7 $\pm 0.4 \mathrm{ka})$, where the top slightly sloping surface was sampled. $(\mathbf{F})$ Boulder NA6 (6.3 $\pm 0.4 \mathrm{ka})$ is $6 \mathrm{~m} \mathrm{high}$. The bottom two photos are samples of the Navesele rock avalanche. (G) Sampled surface of boulder NA3 $(2.4 \pm 0.2 \mathrm{ka})$. (H) Sampled Navesele bedrock detachment surface of NA4 (5.9 $\pm 0.4 \mathrm{ka})$. 
The Gorte rock avalanche deposit extends from $380 \mathrm{~m}$ a.s.l. in the eastern part to $65 \mathrm{~m}$ a.s.l. in the western sector and covers an area of $\sim 0.53 \mathrm{~km}^{2}$. It is bounded to the east by the Paternoster sliding plane, to the north by the Nago alluvial plain, to the west by the Santa Lucia bedrock ridge and Lake Garda and to the south by the Marocche deposit sourced at Spiaz de Navesele-Salto della Capra. The Santa Lucia ridge and the Doss Penede ridge (Figure 4 ) are $150 \mathrm{~m}$ high and have an asymmetrical profile with gently sloping westfacing dip slopes and subvertical east-facing slopes. Based on location, debris lithology and morphological features, four sectors of the Gorte deposit can be distinguished: Daine, Tiro a Volo, Gorte and Busatte (Figure 4). The obtained ${ }^{36} \mathrm{Cl}$ exposure ages for Gorte rock avalanche boulders range from $4.7 \pm 0.3$ to $7.2 \pm 0.5 \mathrm{ka}$ (Table 1, Figures 5 and 8). These are discussed in more detail below within each specific site context.

The Daine blocky deposits comprise the northernmost sector of the rock avalanche, located next to the right scarp of the Paternoster release area. Here, the largest boulders (5-18 $\mathrm{m}$ in diameter) cluster next to the rocky wall, where the carapace is also particularly visible and pronounced. Moving away from the rock wall, the boulders are rarer and smaller (1-5 m diameter), but a few isolated boulders and pinnacles up to $15 \mathrm{~m}$ high are still present (Figure $8 \mathrm{~B}$ ). The internal structure of the deposit is clast-supported, mostly formed by angular pebbles and cobbles of about $5-10 \mathrm{~cm}$, with a small amount of matrix that becomes even scarcer moving eastwards. All boulders show clear karst structures. Two hummocks are present (15-20 m high, 200-250 m long). They are NE-SW-aligned and thus perpendicular to the direction of the rock avalanche flow. The northernmost hummock shows a double ridge, but the overall orientation remains the same. An OOM boulder (GO7-Figure 8D) atop the easternmost hummock yielded an exposure age of $7.2 \pm 0.5 \mathrm{ka}$. At the northernmost limit of the Daine area, near the Nago plain, a smooth scarp is present within the deposit, possibly marking a secondary (internal) collapse. However, the area is covered by dense vegetation, and the scarp may have been smoothed over the years, making it difficult to identify it unequivocally. The eventual deposit of this secondary failure is not visible, possibly covered by the Nago plain lacustrine sediments.

The Tiro a Volo sector is located south of Daine, from which it is separated by a 40-50 m-wide and 15-30 m-deep depression (Figures 4 and 5). This depression is SE-NW-aligned and thus roughly parallel to the side walls of the niche. The Tiro a Volo area hosts the largest hummock of the whole deposit, being $400 \mathrm{~m}$ long. It does not have a well-defined crest but has a rather flat surface, its west flank being the steepest, with an angle of $\sim 30^{\circ}-40^{\circ}$. The upper part of the hummock, as well as the part facing upstream, is characterized by the presence of many large boulders (1-2 $\mathrm{m}$ in diameter). There are fewer of the really huge blocks $(>5 \mathrm{~m}$ ) compared to the Daine area, even though there are some rare boulders up to $10 \mathrm{~m}$ in size. Two dates were obtained for boulders of OOM atop the described largest hummock. Two notably coherent ages of $6.1 \pm 0.4$ (GO5 and GO6-Figure 8C) were obtained. The northernmost part of the hummock and the side facing westwards are characterized by an almost total absence of clasts larger than $50 \mathrm{~cm}$. Here, the deposit can be classified as sandy silty gravel with cobbles and isolated boulders. From this area, OOM boulder GO8 (Figure 8E) returned an age of $5.7 \pm 0.4 \mathrm{ka}$. These characteristics are the same for the southeastern hummock, even if this one is much smaller ( 200 $\mathrm{m}$ long). The southern limit of the Tiro a Volo sector coincides with the large $(\sim 200 \mathrm{~m})$ and deep ( 30-50 m) Oltrezengol Valley (Figures 4 and 5), which is reported to convey significant subsurface water flow [67]. At the head of this valley, a small ( 100 m long) E-W-aligned hummock with a rather smooth surface is present, just below the Paternoster sliding plane. The head of the valley itself has an amphitheater shape, whilst the lower part of the Oltrezengol Valley is narrower (Figure 4). At the height of this narrowing, at the foot of the biggest Tiro a Volo hummock, there are several very large boulders with diameters of up to $20 \mathrm{~m}$. The amphitheater shape, even in the absence of a marked backscarp that could have been smoothed over time, could have also formed during a secondary failure of the deposit in the immediate aftermath of the Gorte rock avalanche. However, a deposit of this collapse is not clearly visible. 
The Gorte sector has a NE-SW elongated shape and extends to the north from the Nago alluvial plain to the south at the Busatte deposit sector. It is bounded to the west by the bedrock ridge of Santa Lucia. This sector is characterized by the extremely rare presence of large (5-10 $\mathrm{m}$ in diameter) boulders, also caused by the extensive reworking of the area by anthropogenic activities. No outcrops were located to evaluate the internal structure of the deposit. Next to the Santa Lucia ridge, a NE-SW-aligned hummock is present ( $\sim 500 \mathrm{~m}$ long). Three other smaller hummocks are present in the Gorte area. The two biggest hummocks are NE-SW-aligned, $\sim 350 \mathrm{~m}$ long, have an elliptical shape and a flat top and are less than $10 \mathrm{~m}$ high. The smallest hummock, $250 \mathrm{~m}$ long, is located in the northern sector of Gorte and has a rough N-S alignment. The Gorte deposit is transversally cut by an incision ( 30 m deep, $200 \mathrm{~m}$ wide) that connects the Nago plain and the Busatte area. In the Gorte sector, two samples (GO9-TOF, GO10-OOM) were dated, returning ages of $7.0 \pm 0.4$ and $4.7 \pm 0.3 \mathrm{ka}$, respectively (Figure 4). The GO10 age is the youngest of the rock avalanche deposit.

The Busatte area comprises the most distal sector of the Gorte rock avalanche deposit. It extends from $\sim 160$ to $65 \mathrm{~m}$ a.s.1., where it reaches Lake Garda. This deposit can be subdivided into two sectors: the upper one, rather flat, and the lower one, showing a mean slope of about $15^{\circ}-20^{\circ}$. The latter has undergone marked anthropogenic modifications; various boulders up to $2 \mathrm{~m}$ in size are still visible, but no larger ones have been found, and no open sections are present to evaluate the internal structure of the deposit. The former is rather flat and shows small semi-circular hummocks, $5 \mathrm{~m}$ high. They are slightly ESE-WNW-aligned and almost parallel to the rock avalanche flow. They show a carapace, with boulders on top up to $5 \mathrm{~m}$ large. In the eastern side of the Busatte area, a plain sector $\sim 0.1 \mathrm{~km}^{2}$ wide is present. Here, fine sediments deposited over the rock avalanche thanks to the running waters conveyed by the Oltrezengol Valley that nowadays creates a swampy area. There, sands dominate, whilst boulders and rock fragments are almost absent. In the Busatte sector, exposure ages were obtained from two boulders, both of TOF. NA5 has been exposed since $5.7 \pm 0.5 \mathrm{ka}$, and NA6 since $6.3 \pm 0.4 \mathrm{ka}$.

\subsubsection{Spiaz de Navesele Rock Avalanche}

The deposit of the Spiaz de Navesele-Salto della Capra event is located between the base of these sliding planes and Lake Garda, in the southernmost sector of the study area. It is named "Marocche" and extends from 220 to $65 \mathrm{~m}$ a.s.l. The deposits cover an area of $\sim 0.23 \mathrm{~km}^{2}$.

The Spiaz de Navesele-Salto della Capra release area is located south of the Paternoster area (Figures 4 and 5). Despite having different names, these two sectors are adjacent and are separated only by a subvertical scarp (several meters high) that is roughly E-W-oriented. As a whole, the area is semi-circular in shape, with vertical scarps on the northern, eastern and southern sides (Figure 5). It extends over $\sim 0.45 \mathrm{~km}^{2}$, at an elevation ranging from 590 to $200 \mathrm{~m}$ a.s.l. The sliding plane, as well as the southern and eastern scarps, is made of TOF. The former is parallel to the bedding and has a dip direction of $~ 300-320$, with a dip angle varying from $25^{\circ}$ in the upper part to $35^{\circ}$ in the lower sector. The sliding plane is crossed by several bedrock steps up to $10 \mathrm{~m}$ high that are roughly ENE-WSW-aligned (Figure 6). Lineaments striking E-W are common in this sector. An age of $5.9 \pm 0.4 \mathrm{ka}$ (NA4) was determined for a sample from the westernmost part of the TOF bedrock sliding plane (Figures 4 and $8 \mathrm{H}$ ).

The deposits (Marocche) related to the Spiaz de Navesele-Salto della Capra dipslope sliding plane are completely made of TOF debris and show distinct morphologies: a relatively flat $\left(5^{\circ}-10^{\circ}\right)$ eastern part, and a steeper $\left(30^{\circ}-35^{\circ}\right)$ western sector. The former is made of rock debris ranging from cobbles to pebbles, with a small amount of fine matrix. Several boulders $\sim 1 \mathrm{~m}$ in diameter are present, with larger ones (up to $8 \mathrm{~m}$ high) clustered near the sliding plane. To the west, there is an NNE-SSW-oriented hummock that is several meters high. It is characterized by a clast-supported deposit, with boulders $>5 \mathrm{~m}$. To the west of the hummock, a smooth scarp is present, possible due to a post-event (secondary) 
collapse of the Marocche deposit. The related deposit can be recognized under the lake in the bathymetric relief (Figures 4 and 5). The orientation and elevation of the hummock suggest that Marocche deposits overlie deposits of the Gorte landslide. This would be consistent with the exposure age of sample NA3 (TOF) collected from the flat top of a large boulder (Figure 8G), returning the age of $2.4 \pm 0.2 \mathrm{ka}$. Nevertheless, the age from the sliding surface suggests a much older age for the Navesele event (see below).

\subsection{Topographic Reconstruction and Volume Analysis}

We used the procedure detailed in Section 3.3 to reconstruct the pre-failure topography and to estimate the source and deposit volumes. Starting with the source zone, we estimated that a volume of $70-75 \mathrm{Mm}^{3}$ was released from the Paternoster niche. Given the well-defined shape of the release area, the uncertainties mainly concern the location of the base of the landslide, as scree deposits, as well as rock avalanche deposits in the lower section, obscure the depth of the sliding surface. Between $680 \mathrm{~m}$ a.s.l. (the highest part of the Paternoster release area) and $380 \mathrm{~m}$ a.s.l., we removed a small volume of scree that was deposited after the landslide. Between $380 \mathrm{~m}$ a.s.l. and the bottom of the release area (labeled Tiro a Volo and Daine on Figure 4), thick deposits of rock avalanche material obscure the rupture surface. We therefore interpreted the sliding plane to have a lower slope $\left(15^{\circ}\right)$ with respect to the slope in the upper release area $\left(25^{\circ}\right)$.

For the deposit, we estimated a volume of $85-95 \mathrm{Mm}^{3}$, which leads to a bulking of $\sim 26 \%$, similar to the typical value of $25 \%$ estimated by [62]. We subdivided the deposit into three main areas (Figure 4): (1) a part remaining in the detachment niche that forms the hummocks of Daine and Tiro a Volo (Figure 5), (2) a part not visible today that is buried below the Nago plain and (3) a large part of the deposit that extends from the Nago plain to Lake Garda, in the locality of Gorte and Busatte (Figure 5).

The reconstruction of the surface below the Daine and Tiro a Volo is described above, and the other two deposit zones were reconstructed based on the following considerations. Core logs and geophysical data in the Passo San Giovanni area indicate that the transition from alluvial to lacustrine sediments is at an approximate elevation of $180 \mathrm{~m}$ a.s.l. [42]. Furthermore, the level of Lake Garda after the Last Glacial Maximum has not changed significantly in the last 10,000 years, reaching a maximum of $70 \mathrm{~m}$ a.s.l. and a minimum of $62 \mathrm{~m}$ a.s.l. (present level $65 \mathrm{~m}$ a.s.l.) [68]. Therefore, an alluvial plain extending from the Passo San Giovanni to Lake Garda was reconstructed. The slope of this alluvial plain was assumed constant between the two points whose elevations are known. The east side of the paleovalley was reconstructed with a slope similar to the mountainside, which increases to $35^{\circ}-40^{\circ}$ towards the lake. The west side of the paleovalley was reconstructed with nearvertical slopes, based on the bedrock outcrop visible just north of Busatte (Figure 4). This reconstructed morphology resembles the nearby ridges of Santa Lucia and Doss Penede.

\subsection{Runout Analysis}

Following the reconstruction of the pre-failure topography, we performed numerical runout modeling based on the methodology described in Section 3.4. The initial calibration step resulted in a best-fit bulk friction angle of $14^{\circ}$ and a flexible block time of $10 \mathrm{~s}$. As described above, the reconstructed rupture surface is compound, and thus movement over this surface requires internal deformation of the failed mass. We expect that fluidization of the initial failure occurred when the center of mass moved from the upper part, where the sliding plane is steeper, to the lower part with the less steep plane. A friction coefficient of 0.38 and turbulence coefficient of $700 \mathrm{~m} / \mathrm{s}^{2}$ were found to provide the best-fit Voellmy parameters between the simulated and observed runout. Interestingly, these values are comparable to back-analyses of case histories that overran the bedrock $[7,24,69,70]$.

Figure 9 shows the simulation results obtained at different times using the best-fit parameter combination. At $20 \mathrm{~s}$, the rigid sliding phase is already finished, and the landslide follows a frictional rheology inside the release area, while the landslide foreground part in the paleovalley of Gorte follows a Voellmy-type rheology. It can be seen that after 
$20 \mathrm{~s}$, the toe of the landslide has already reached the bottom of the paleo valley, and at this moment, the landslide divides into two lobes deflected by the ridge of Santa Lucia, spreading in the SW direction towards Lake Garda and in the NE direction towards the current Nago plain. After $40 \mathrm{~s}$, the landslide reaches the top of the ridge of Santa Lucia, and the Gorte paleovalley is already filled, with the depth of the deposit exceeding $100 \mathrm{~m}$. A considerable part of the deposit is still inside the release area, with a significant thickness in the area of Daine. After $60 \mathrm{~s}$, the landslide deposit begins to assume its final shape, and the two lobes achieve their maximum extensions, just reaching the shoreline of Lake Garda in the southern lobe. The Paternoster area is still partially covered by several tens of meters of debris. After $120 \mathrm{~s}$, the movement of the rock avalanche can be considered complete, with the deposit taking its final outline.

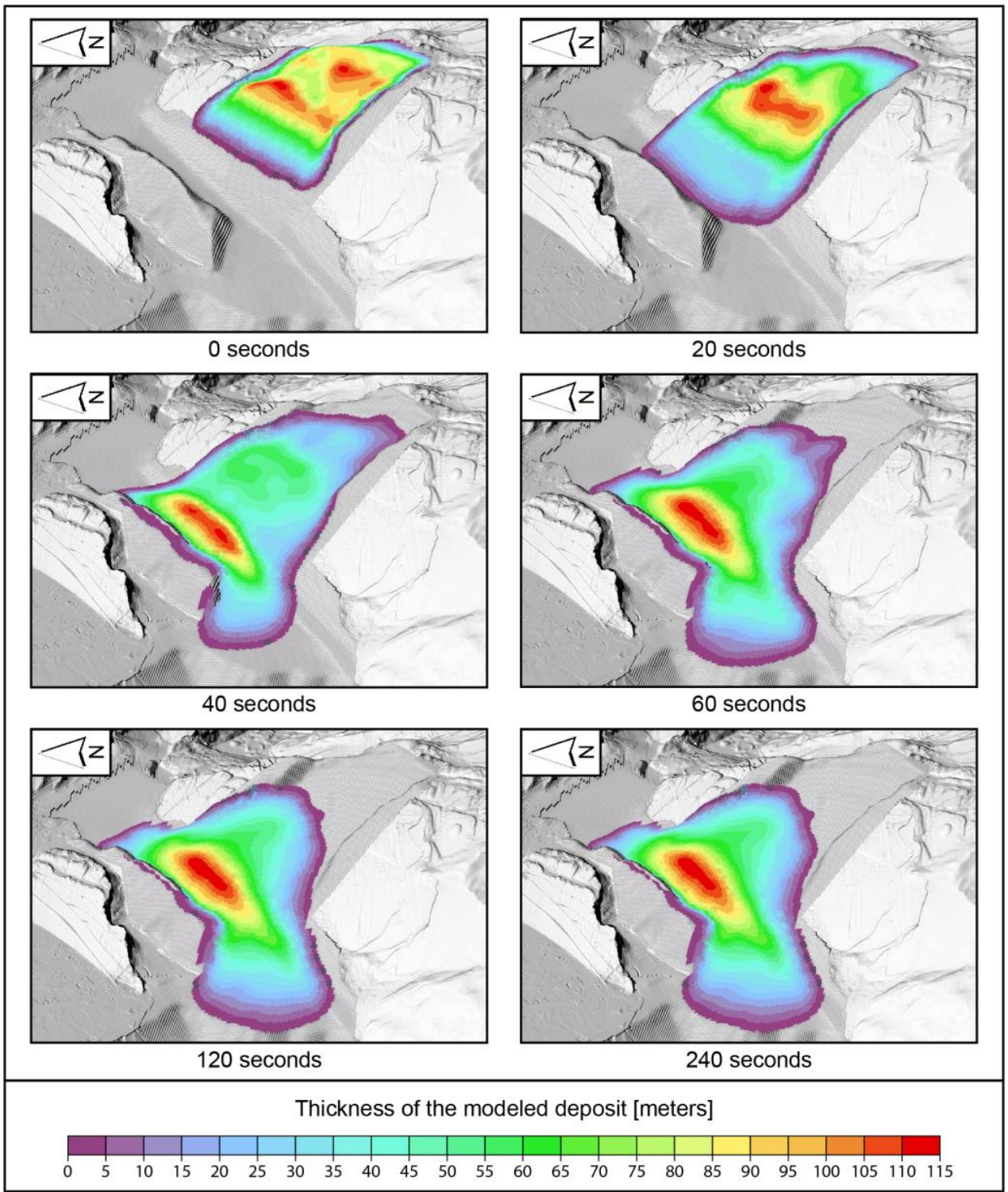

Figure 9. 3D overview of Dan3D-Flex modeling results for runout distance and thickness over time (for details, see text). The rock avalanche impacts and is deflected by the Santa Lucia ridge. For reference, the approximate length of this ridge is $1 \mathrm{~km}$.

The modeled deposit extent is similar to the actual extent (Figure 10). The extent under the Nago plain is not known due to the lack of subsurface data. In our model, the western lobe in the direction of Lake Garda is larger than the eastern lobe. This is because the interpreted paleovalley descends steeply in the direction of the lake, while to the east 
towards Nago, the paleovalley rises gently. In the model results, the landslide deposit is thickest $(114 \mathrm{~m})$ in the paleovalley just to the east of the Santa Lucia ridge. The thickness of the modeled deposit decreases in the direction of the two lobes to the east and west.

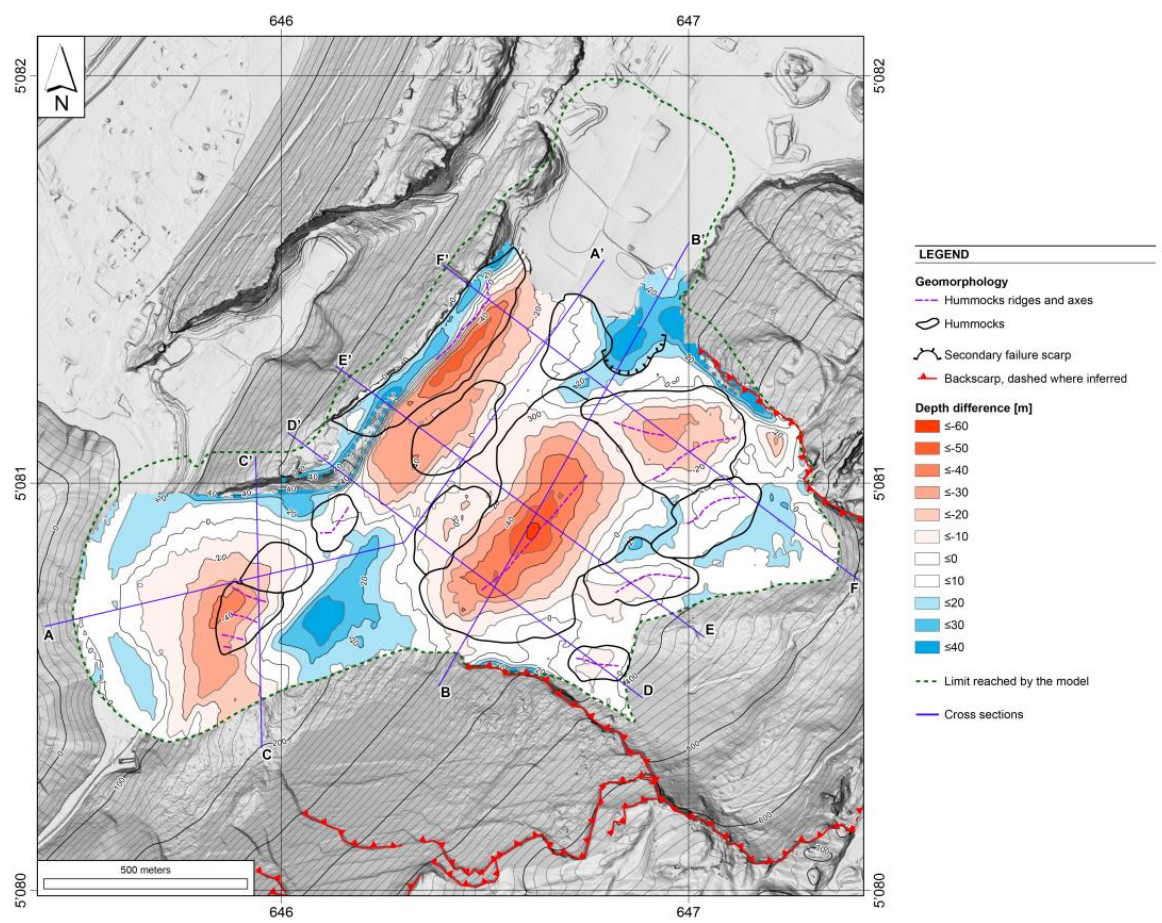

Figure 10. Map showing difference between the best-fit Voellmy parameter simulation of the landslide topography and the actual present-day topography. Negative values indicate that the simulated elevation is below the present topography. Extreme values around cliffs, as well as the part below the lake sediments, have been removed. In blue are the locations of the cross-sections shown in Figure 11.
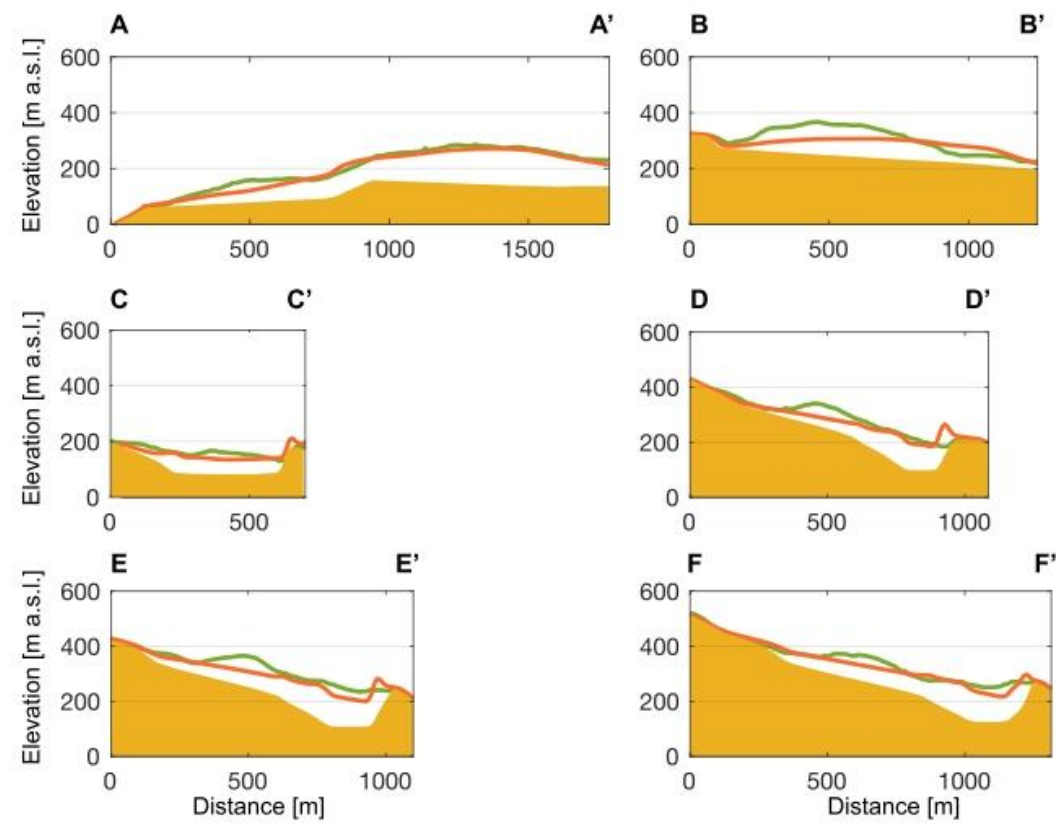

Present-day topography

Modelled landslide deposit

Reconstructed topography

Figure 11. Cross-sections through the landslide deposit with the best-fit parameters of the Voellmy rheology. The topography based on modeling (red line), the present-day topography (green line) and the reconstructed pre-failure topography used for modeling are shown. The scale is the same for every segment. The location of the cross-sections is visible in Figure 10. 
Figure 10 shows the elevation differences between the modeled landslide topography and the actual topography, and Figure 11 compares various cross-sections of the measured and estimated deposit depths. In Figure 10, the white colors show the area where the elevations of the modeled and actual landslide deposits are similar. In contrast, the red areas indicate where the modeled deposit is thinner than the actual one, while the blue areas indicate where it is thicker. Extreme values shown at the cliffs, particularly at the northern flank and in the southernmost corner of the Santa Lucia ridge, are not to be considered real differences but artifacts due to the presence of steep cliffs in these areas. The deposit below the lake sediments of the Nago plain has been removed, as, there, it is not possible to precisely define the real thickness of the lacustrine sediments. Overall, Figures 10 and 11 show that there is good agreement between the actual and modeled deposit thicknesses, which only differ where the large hummocks are present, especially in the Daine, Tiro a Volo and Gorte sectors. A similar observation has been noted in runout modeling results for the nearby Molveno rock avalanche [12].

\section{Discussion}

\subsection{Release and Emplacement of the Two Studied Landslides}

\subsubsection{The Gorte Rock Avalanche}

The eight determined ${ }^{36} \mathrm{Cl}$ boulder exposure ages for the Gorte deposit yield an average of $6.1 \pm 0.8 \mathrm{ka}$ (Figure 12), including all eight ages (GO5, GO6, GO7, GO8, GO9, GO10, NA5, NA6). Approximately 6100 years ago, an $800 \times 1000 \times 100 \mathrm{~m}$ block of OOM, TOF and RTZ limestones detached along the head scarp and side walls and began sliding down bedding planes. This was likely promoted and facilitated by interbedded thin marl layers in RTZ. Detachment was controlled by three recognized lineaments; the backscarp follows an $\mathrm{S}_{2}$ surface with an NNE-SSW orientation and a $74^{\circ}$ dip, and the two lateral scarps follow discontinuity set $S_{3}$ which is nearly vertical and is oriented WNW-ESE. Furthermore, our modeling supports the hypothesis that downslope movement was initially translational as a rock slide. After about $10 \mathrm{~s}$, likely related to a kink in the bedrock plane, the mass began to break up but continued its movement in a northwest direction (Figure 9).

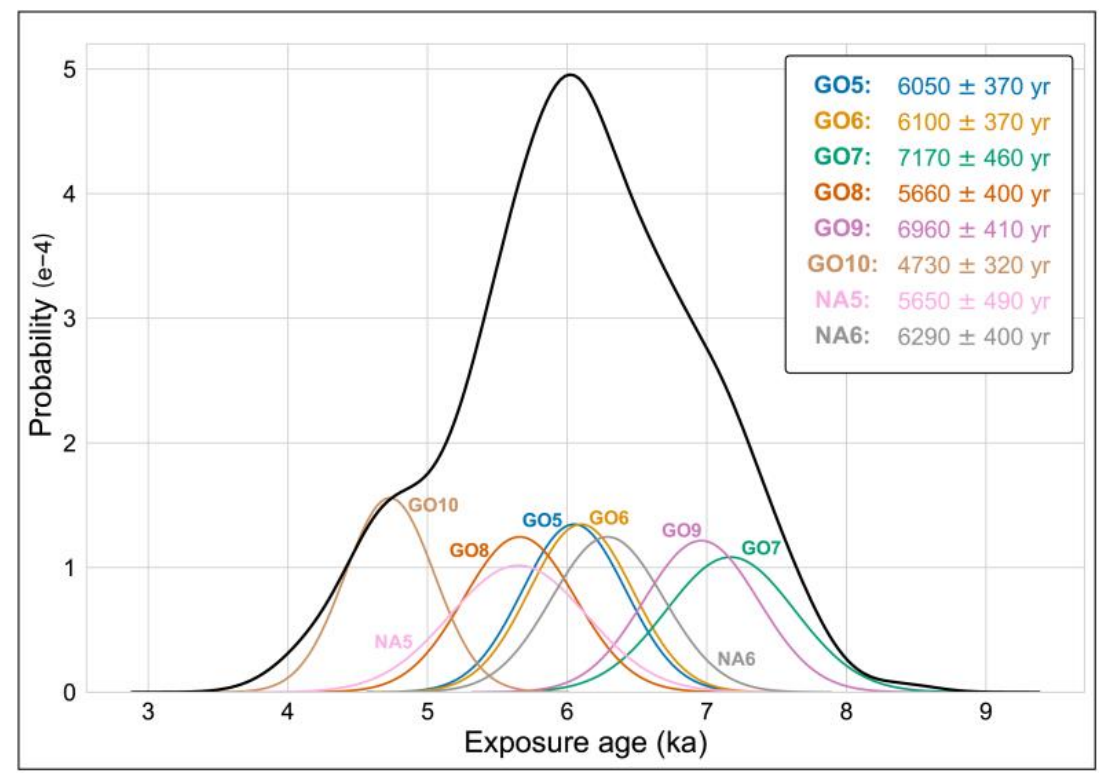

Figure 12. Camel plot for the eight ${ }^{36} \mathrm{Cl}$ exposure ages for boulders from the Gorte rock avalanche deposits. Colored lines show individual exposure ages and the Gaussian distribution of the uncertainties. The black line indicates the summed probability distribution for the dataset. The mean of the ages is $6.1 \pm 0.8 \mathrm{ka}$.

Several hummocks dominate the topography of the Gorte deposits, providing additional information on the emplacement dynamics [11,13,71]. The largest are those of Daine 
and Tiro a Volo, which are aligned in an NE-SW direction and thus transverse to the flow direction of the landslide. In contrast, in the lower part of the deposit, hummocks are smaller in size, and are oriented longitudinally with respect to the flow direction (Figure 5). The former imply formation due to compressional forces connected to slowing during emplacement, perhaps related to steps in the underlying bedrock. The latter formed due to extensional processes related to spreading and differential velocities within the moving mass [71].

The morphology of the deposit (Figure 5) and the runout modeling results (Figure 9) indicate that the paleovalley located east of the Santa Lucia ridge (Figure 4) filled with blocky debris as the moving mass slowed due to impact with the steep eastern wall of that ridge. This impact deflected part of the moving debris to the west and part to the east. Neither field evidence nor modeling results indicate overtopping of the Santa Lucia ridge by the rock avalanche. The Gorte hummock, located right against the Santa Lucia ridge, is oriented parallel to both the bedrock ridge and the large transverse hummocks in the Daine and Tiro a Volo areas. We interpret that the elongated and narrow shape of this hummock is related to the blockage of the rock avalanche flow by the rocky ridge of Santa Lucia, which hindered its spreading to the west. Debris from the Gorte rock avalanche may have made it all the way into Lake Garda. Nevertheless, looking at the bathymetric data (Figure 5), no structures linked to deposits within the lake below the Busatte sector are evident. Some large (up to $18 \mathrm{~m}$ in diameter) isolated boulders are visible on a fan-delta-like morphology. However, given the absence of a direct connection with the other deposits described herein, their origin cannot be attributed with certainty.

The Gorte deposit blocked the westward-directed drainage of the paleovalley connecting the Passo San Giovanni area and Lake Garda (Figure 4). As a result, a lake formed. It filled up to the level of the outlet to the north, forming the Nago plain. Nevertheless, the age of infillings beneath the Nago plain and the possible occurrence of previous blockages related to earlier gravitational events cannot be discerned with the presently available data on the basin infill.

\subsubsection{The Spiaz de Navesele Rock Avalanche}

The blocky Marocche deposits of the Spiaz de Navesele event overlie and thus stratigraphically postdate the Gorte deposits. At present, chronological data do not allow us to fully decipher the timing of the Spiaz de Navesele event in comparison to the Gorte event. A single boulder was dated in the Marocche deposit at the foot of the Spiaz de Navesele sliding plane. It was located in an area that is strongly disturbed by anthropogenic activity, including numerous stone cairns. This single age $(2.4 \pm 0.2 \mathrm{ka})$ is difficult to interpret, and further dating would be necessary to determine if the Navesele event is several thousand years younger than the Gorte event or if the age of the bedrock sliding surface (5.9 $\pm 0.4 \mathrm{ka})$ provides a more realistic age. In that framework, the Gorte and Navesele events would have occurred almost simultaneously. Note that the right-hand boundary of the Spiaz de Navesele detachment surface stands as the left-hand steep side wall of the Gorte detachment niche. This is in line with the hypothesis that the Gorte event triggered the Spiaz de Navesele event.

The structural setting in Spiaz de Navesele-Salto della Capra is controlled by ENE-WSW lineaments (Figures 2 and 6). This allowed the landslide to flow and to spread in several directions, thus reducing the thickness of the deposit at Marocche (Figures 4 and 5) and explaining the lower slope in the Gorte southern area, which represents the transition zone between the lower paleovalley and the wide plain present at the time in the Busatte area. The large hummock in the Marocche deposit is oriented NE-SW and thus lies transverse to the direction of motion, implying limited mobility of the Spiaz de Navesele event.

\subsubsection{Other Deposits in the Study Area}

Our results from the Gorte and Spiaz de Navesele landslides provide an initial insight into the spatial and temporal relationships of the several landslide deposits in the Torbole- 
Nago-Passo San Giovanni region. Yet, further study is required to understand the toma on the Nago plain and the blocky and hummocky deposits known as Mala located at Passo San Giovanni (Figure 4). Previous authors have suggested that the toma hills on the Nago plain (Figures 4 and 5) are related to a detachment from the Segron release area [28]. The toma hills appear to be buried along the base by the alluvial/lacustrine sediments of the Nago plain. This suggests that they are older than the timing of the lake formation but would also require that the lake was rather shallow. On the other hand, the tomas themselves may have formed during the Gorte event. Excessive runout of tomas (several kilometers) has been observed at the Flims [72] and Fernpass landslides [73]. Many of the tomas on the Nago plain are barely recognizable, having been strongly reshaped by human activity. No blocks suitable for exposure dating could be located.

To the east of these tomas are the Mala deposits, which are located near the hummocky terrain further to the east (Figure 4). The release area related to the Mala deposits is the north slope of Doss dei Frassini [28], and possibly the slopes to the north of Loppio Valley as well. The Mala deposits are not covered by Nago plain sediments; therefore, the Mala event is younger. The Mala deposits blocked the Loppio Valley, isolating the Nago plain from the eastern sector of the valley, where Lake Loppio formed and is still present as a very shallow lake. Finally, [74] reported that a minor detachment occurred in 1457 AD, whose deposit ended up on top of the larger Mala deposit at Passo San Giovanni.

\subsection{Causes, Triggers and Relationship with Other Large Landslides in the Region}

The reporting of a relatively large event near Passo San Giovanni only a few centuries ago and the recent (January 2021) event along the Lake Garda slope underline the importance of understanding the contributing causes and triggers for slope failures in this region. In the recent event, $800-900 \mathrm{~m}^{3}$ of RTZ slid towards the lake on the dip slope and blocked the main road for several weeks. The bedrock slopes along both sides of Lake Garda have been undercut and oversteepened during repeated glaciations [75], which can predispose them to failure [24]. During the Last Glacial Maximum, the Nago-Torbole area was completely covered by the combined Sarca-Adige glacier lobe that flowed down the Sarca Valley. The frontal position, located just south of Lake Garda, was maintained between $\sim 24.7$ and $\sim 17.5 \mathrm{ka}$ cal BP [75,76]. In the region of our study site, the elevation of the glacier reached $750 \mathrm{~m}$ a.s.l. [41], completely submerging the Gorte release area beneath the glacier.

Faults and fractures in the rock related to the main regional fault systems, the Giudicarie and the Schio-Vicenza, have been shown to have played a decisive role in slope failures of the region [19]. In the Gorte release area, the identified $S_{2}$ and $S_{3}$ sets are linked to the regional tectonics of the Lake Garda and Sarca catchment. The $S_{2}$ set (NNE-SSW) is related the Giudicarie fault system. The Schio-Vicenza fault system, normally with a subvertical NW-SE orientation, is represented here by $S_{3}$ lineaments. The landslide backscarp is characterized by a cliff (about $60 \mathrm{~m}$ high) along an imposing NNE-SSW fault plane located northwest of Doss dei Frassini. This fault plane is likely connected to the Giudicarie fault system (Figures 2, 5 and 6). The northern and southern flanks, instead, are connected to the Schio-Vicenza NW-SE fault system. Two ridges in the Paternoster release area, which contributed to shaping the topography of the rupture plane, are oriented NNE-SSW and ENE-WSW. The $S_{0}$ set (bedding) shows inclinations between $25^{\circ}$ and $35^{\circ}$ and is one of the predisposing factors for the landslide (Figure 6).

The lithology played an important role because the rupture plane likely developed within the RTZ marly interlayers that are rich in coal or include black shales [41]. These interlayers were not observed in the Paternoster release area, having likely been eroded over the millennia after the collapse. Given the smaller friction angle of the marly RTZ interlayers, sliding was possible with bedding at an inclination of $25^{\circ}$, as it is seen in the Paternoster area. The marly interlayers have also been detected in the release areas of other landslides including the nearby Marocche of Dro and Molveno rock avalanches [12,16] and the well-known Vajont landslide [77]. Another predisposing factor of the landslide 
can be the presence of caves in the release area. As already discussed, several large caves (several decameters) are present in the Doss dei Frassini side walls [78]. These types of caves represent a further weakening factor of the rock mass [79-81], as in the case of the Masiere di Vedana rock avalanche, where several caves have been identified in the same lithological formation [17].

Connected to the caves, a karstic aquifer system is present along the relief, whose base level is represented by Lake Garda [45] with ephemeral springs inside the Busatte area ("Romani spring"), whereas the release areas and the sliding planes have neither springs nor surface runoff [67]. Underneath the Paternoster release area and the sliding planes of Spiaz de Navesele-Salto della Capra, the Adige-Garda tunnel was excavated to avoid the danger of flooding of the Adige Valley and to discharge part of the Adige River into Lake Garda [45].

The combination of the predisposition factors listed above requires a trigger to cause the rock slope failure. The first hypothesis is that the trigger was of a seismic origin. Seismic activity in the area has been extensively documented over the years, with earthquakes in the region of Lake Garda reaching, in historical times, a level on the Mercalli-Cancani-Sieberg intensity scale (MCS) of IX such as the earthquakes of Verona in 1117 AD and Brescia in $1222 \mathrm{AD}$ [39]. More than one earthquake with an equivalent magnitude of around 5 with its epicenter in the area of Monte Baldo, about $15 \mathrm{~km}$ south of Nago-Torbole, has been recorded in the last two centuries [39]. The hypocenters of several recent earthquakes were located both along the Giudicarie belt and the Schio-Vicenza and other nearby minor faults [38,82]. Several historical landslides in the area such as Castelpietra, Kas, Prà da Lago and Varini (Lavini di Marco) [16,30], all within $15 \mathrm{~km}$ from the Nago-Torbole, were attributed to seismic crises, such as the "Middle Adige Earthquake" of 1046 AD, believed to be the cause of the Castelpietra landslide [26]. Recently, the hypo thesis of a common seismic trigger during the Middle Holocene has also been raised for the Marocche di Dro (Marocca Principale), $5.3 \pm 0.9 \mathrm{ka}$, and the Marocca di Molveno, $4.8 \pm 0.5 \mathrm{ka}[12,83]$, located 13 and $25 \mathrm{~km}$ to the north, respectively.

The second trigger to be taken into consideration is the climate, particularly a humid climate with periods of heavy, persistent rainfall characterizing part of the Holocene. In the Holocene, three periods with a marked concentration of landslides were identified in the time intervals 10-9 ka, 5-3 ka and 2-1 ka, the last one especially for south of the Alps [15,16]. For the period 5-3 ka, an increased frequency of landslides can be traced back to a shift to a wetter climate, but also colder climatic conditions, whose extreme was reached around $4.2 \mathrm{ka}$, representing the transition from the Middle to the Late Holocene [15]. This period is characterized by both a general trend and the occurrence of individual extreme weather events, both locally and all over Europe [84,85]. The increase in landslides corresponding to extreme weather events and, in general, of humid periods is due to an increase in pore water pressure, which causes a reduction in the effective stress, thus inducing collapse $[86,87]$. The cyclicity of these events could then induce fatigue in the rock mass [86] that would lead to eventual failure. Our dating of the Gorte rock avalanche places it in the Middle Holocene period 7-5 ka, where Europe was characterized by warmer temperatures in summer and winter [88], and suggests a marked reduction in precipitation at the Alpine scale [89]. However, embedded in this period was an interval of frequent flooding on the northeastern Po Plain (Venetian plain) at 6900-6200 years ago [84], located just to the east of our study site.

Looking at the landslides already dated in the surroundings of the Gorte landslide (Figure 2), a very similar age has been calculated for the Dosso Gardene landslide, located adjacent to Lavini di Marco, about $11 \mathrm{~km}$ east of the study area. In this case, the buried soil below the landslide deposit was dated 6630-6290 cal BP [31], in agreement with the error of the Gorte rock avalanche $(6.1 \pm 0.8 \mathrm{ka})$, and at the limit of the landslide of Spiaz de Navesele $(5.9 \pm 0.4 \mathrm{ka})$. Additionally, the Marocca Principale of the Marocche di Dro $(5.3 \pm 0.9 \mathrm{ka})$ falls within the error range of the Gorte and the Spiaz de Navesele-Salto della Capra landslides. Nonetheless, the Marocca Principale has an age more similar to the 
Molveno landslide ( $4.8 \pm 0.5 \mathrm{ka}$; [12]), which, for the enormous volume of both, suggests a common trigger. The distance between the Molveno and Marocca Principale, visible in Figure 2, is about $13 \mathrm{~km}$ and is the same in the opposite direction to the Nago-Torbole area. Considering the increasingly evident correlation of several landslides in the area linked to seismic events, it is possible that the Gorte and Spiaz de Navesele-Salto della Capra landslides were triggered by an earthquake, which may have also been responsible for the landslides of Dosso Gardene or Marocca Principale.

\section{Conclusions}

The region of Nago-Torbole at the northeast end of Lake Garda is the site of numerous landslides. We applied geomorphological field mapping, dating with cosmogenic ${ }^{36} \mathrm{Cl}$, topography reconstruction, volume estimation and runout modeling to study the landslides and deposits of Gorte and Spiaz de Navesele-Salto della Capra, for which we can present the following results:

- Despite the various uncertainties linked to the topographical reconstruction, the Gorte rock avalanche has a bedrock volume in the release area of about $70-75 \mathrm{Mm}^{3}$, with a deposit volume of about $85-95 \mathrm{Mm}^{3}$. The lithologies involved in the Gorte landslide are the Massone Oolite, the Rotzo and the Tofino Formations.

- The release area (Paternoster) is strongly affected by fractures related to regional-scale fault systems. The structural setting controls the bedding inclination to the west $\left(25^{\circ}-35^{\circ}\right)$. The Schio-Vicenza fault system controls the WNW-ESE-oriented flanks of the landslide, whereas the backscarp is formed by an important NNE-SSW fault belonging to the Giudicarie fault system. The flow was initially a translational rock slide with associated toppling from the surrounding steep scarps.

- The Gorte rock avalanche deposit is characterized by large hummocks, both longitudinal and transversal to the rock mass flow. Within the deposit, secondary failures occurred. The blocky carapace is not homogeneously distributed, but there are zones with abundant large blocks, while other areas are completely boulder-free.

- Our ${ }^{36} \mathrm{Cl}$ boulder exposure dates underpin the hypothesis that the Gorte rock avalanche happened in a single event. The age obtained is $6.1 \pm 0.8 \mathrm{ka}$.

- The Gorte rock avalanche dates to a relatively warm and dry period of the Middle Holocene. Nevertheless, a period of frequent flooding at 6900-6200 was recognized for the region and overlaps the timing of the Gorte rock avalanche. The age is comparable to the age of the Dosso Gardene landslide (6630-6290 cal BP), as well as the Marocca Principale $(5.3 \pm 0.9 \mathrm{ka})$, both within $15 \mathrm{~km}$. The important seismic activity still ongoing nowadays makes it likely that the trigger of the landslide may have been seismic activity.

- The Gorte landslide was characterized by initial rock sliding followed by disintegration and spreading. To simulate the flow of the rock avalanche, using Dan3D-Flex, two different rheologies were tested. The model that reproduced the best results used a frictional rheology in the source area with a friction angle of $14^{\circ}$, and a turbulent frictional rheology (Voellmy) in the rest of the area, with a friction coefficient of 0.38 and a turbulence coefficient of $700 \mathrm{~m} / \mathrm{s}^{2}$.

- The sliding of Spiaz de Navesele-Salto della Capra took place south of Gorte, involving the Tofino Formation. The related deposit, named Marocche, formed a hummock over the Busatte area.

- The sliding of Spiaz de Navesele-Salto della Capra took place at the same time or immediately after the Gorte rock avalanche: it was dated to $5.9 \pm 0.4 \mathrm{ka}$, but by means of a single bedrock sample. It is not to be excluded that the sliding took place in several phases, with more or less regular detachments over the millennia. A second sample, a boulder in the deposit, indicates an age of $2.4 \pm 0.2 \mathrm{ka}$, but anthropogenic influence cannot be excluded. 
Supplementary Materials: The descriptions of the thin sections obtained from sampled boulders are available online at https:/ / www.mdpi.com/article/10.3390/geosciences11100404/s1, Figure S1: Thin sections from sampled boulders.

Author Contributions: Conceptualization, S.I.-O. and S.M.; data curation, G.R., S.I.-O., O.S. and C.V.; funding acquisition, S.I.-O. and S.M.; investigation, G.R., S.I.-O., J.A., O.S., S.M., M.R., S.R., C.V., G.M. and A.V.; methodology, G.R., S.I.-O., J.A., O.S., M.R., S.R. and C.V.; resources, S.I.-O. and S.M.; supervision, S.I.-O. and S.M.; visualization, G.R., O.S. and S.R.; writing-original draft, G.R., S.I.-O., J.A., S.M., S.R. and G.M.; writing—review and editing, G.R., S.I.-O., J.A., O.S., S.M., M.R., S.R., C.V., G.M. and A.V. All authors have read and agreed to the published version of the manuscript.

Funding: This research was funded by the Department of Geosciences of the University of Padova, grant number "SID 2020"; project title: "Historic and prehistoric landslides in the Alps. Implications for new hazard maps in mountainous areas. Focus on the Lake Garda-Brenta Dolomites sector (NE Italy)".

Data Availability Statement: All data mentioned in this paper are included within the manuscript and the Supplementary Material.

Acknowledgments: The authors are grateful to the Province of Trento for the measurements on rock parameter data and the availability of the LiDAR DEM, and to the Marina Militare Italiana for bathymetry data. Fieldwork, laboratory work and AMS measurements were partially funded by Ion Beam Physics, ETH Zurich. Matteo Visintainer is acknowledged for the photo used in Figure 3.

Conflicts of Interest: The authors declare no conflict of interest. The funders had no role in the design of the study; in the collection, analyses, or interpretation of data; in the writing of the manuscript, or in the decision to publish the results.

\section{References}

1. Rossato, S.; Martin, S.; Ivy-Ochs, S.; Viganò, A.; Vockenhuber, C.; Rigo, M.; Surian, N.; Mozzi, P. Post-LGM Catastrophic Landslides in the Dolomites: When, Where and Why. Alp. Mediterr. Quat. 2018, 31, 239-242.

2. Rossato, S.; Ghirotti, M.; Gabrieli, F.; Livio, F.; Bovo, F.; Brezzi, L.; Campedel, P.; Cola, S.; Ivy-Ochs, S.; Martin, S.; et al. Learning from the Past to Face the Future: Landslides in the Piave Valley (Eastern Alps, Italy). Alp. Mediterr. Quat. 2020, 33, 209-228. [CrossRef]

3. Strouth, A.; McDougall, S. Societal Risk Evaluation for Landslides: Historical Synthesis and Proposed Tools. Landslides 2021, 18, 1071-1085. [CrossRef]

4. Kremer, K.; Simpson, G.; Girardclos, S. Giant Lake Geneva Tsunami in AD 563. Nat. Geosci. 2012, 5, 756-757. [CrossRef]

5. Köpfli, P.; Grämiger, L.M.; Moore, J.R.; Vockenhuber, C.; Ivy-Ochs, S. The Oeschinensee Rock Avalanche, Bernese Alps, Switzerland: A Co-Seismic Failure 2300 Years Ago? Swiss J. Geosci. 2018, 111, 205-219. [CrossRef]

6. Semenza, E.; Ghirotti, M. History of the 1963 Vaiont Slide: The Importance of Geological Factors. Bull. Eng. Geol. Environ. 2000, 59, 87-97. [CrossRef]

7. Aaron, J.; McDougall, S. Rock Avalanche Mobility: The Role of Path Material. Eng. Geol. 2019, 257, 105126. [CrossRef]

8. McDougall, S.; Hungr, O. Dynamic Modelling of Entrainment in Rapid Landslides. Can. Geotech. J. 2005, 42, 1437-1448. [CrossRef]

9. Weidinger, J.T.; Korup, O.; Munack, H.; Altenberger, U.; Dunning, S.A.; Tippelt, G.; Lottermoser, W. Giant Rockslides from the Inside. Earth Planet. Sci. Lett. 2014, 389, 62-73. [CrossRef]

10. Dufresne, A.; Dunning, S.A. Process Dependence of Grain Size Distributions in Rock Avalanche Deposits. Landslides 2017, 14, 1555-1563. [CrossRef]

11. Wang, F.; Okeke, A.C.U.; Kogure, T.; Sakai, T.; Hayashi, H. Assessing the Internal Structure of Landslide Dams Subject to Possible Piping Erosion by Means of Microtremor Chain Array and Self-Potential Surveys. Eng. Geol. 2018, 234, 11-26. [CrossRef]

12. Von Wartburg, J.; Ivy-Ochs, S.; Aaron, J.; Martin, S.; Leith, K.; Rigo, M.; Vockenhuber, C.; Campedel, P.; Viganò, A. Constraining the Age and Source Area of the Molveno Landslide Deposits in the Brenta Group, Trentino Dolomites (Italy). Front. Earth Sci. 2020, 8, 164. [CrossRef]

13. Singeisen, C.; Ivy-Ochs, S.; Wolter, A.; Steinemann, O.; Akçar, N.; Yesilyurt, S.; Vockenhuber, C. The Kandersteg Rock Avalanche (Switzerland): Integrated Analysis of a Late Holocene Catastrophic Event. Landslides 2020, 17, 1297-1317. [CrossRef]

14. Mitchell, A.; McDougall, S.; Nolde, N.; Brideau, M.A.; Whittall, J.; Aaron, J.B. Rock Avalanche Runout Prediction Using Stochastic Analysis of a Regional Dataset. Landslides 2020, 17, 777-792. [CrossRef]

15. Zerathe, S.; Lebourg, T.; Braucher, R.; Bourlès, D. Mid-Holocene Cluster of Large-Scale Landslides Revealed in the Southwestern Alps by 36Cl Dating. Insight on an Alpine-Scale Landslide Activity. Quat. Sci. Rev. 2014, 90, 106-127. [CrossRef]

16. Ivy-Ochs, S.; Martin, S.; Campedel, P.; Hippe, K.; Alfimov, V.; Vockenhuber, C.; Andreotti, E.; Carugati, G.; Pasqual, D.; Rigo, M.; et al. Geomorphology and Age of the Marocche Di Dro Rock Avalanches (Trentino, Italy). Quat. Sci. Rev. 2017, 169, 188-205. [CrossRef] 
17. Rossato, S.; Ivy-Ochs, S.; Martin, S.; Viganò, A.; Vockenhuber, C.; Rigo, M.; Monegato, G.; de Zorzi, M.; Surian, N.; Campedel, P.; et al. Timing, Drivers and Impacts of the Historic Masiere Di Vedana Rock Avalanche (Belluno Dolomites, NE Italy). Nat. Hazards Earth Syst. Sci. 2020, 20, 2157-2174. [CrossRef]

18. Oswald, P.; Strasser, M.; Hammerl, C.; Moernaut, J. Seismic Control of Large Prehistoric Rockslides in the Eastern Alps. Nat. Commun. 2021, 12, 1-8. [CrossRef]

19. Viganò, A.; Rossato, S.; Martin, S.; Ivy-Ochs, S.; Zampieri, D.; Rigo, M.; Monegato, G. Large Landslides in the Alpine Valleys of the Giudicarie and Schio-Vicenza Tectonic Domains (NE Italy). J. Maps 2021, 17, 197-208. [CrossRef]

20. Prager, C.; Zangerl, C.; Patzelt, G.; Brandner, R. Age Distribution of Fossil Landslides in the Tyrol (Austria) and Its Surrounding Areas. Nat. Hazards Earth Syst. Sci. 2008, 8, 377-407. [CrossRef]

21. Hovius, N.; Stark, C.P.; Allen, P.A. Sediment Flux from a Mountain Belt Derived by Landslide Mapping. Geology 1997, $25,231-234$. [CrossRef]

22. Korup, O.; Clague, J.J. Natural Hazards, Extreme Events, and Mountain Topography. Quat. Sci. Rev. 2009, 28, 977-990. [CrossRef]

23. Huggel, C.; Gruber, S.; Korup, O. Landslide Hazards and Climate Change in High Mountains. Treatise Geomorphol. 2013, 13, 288-301. [CrossRef]

24. Grämiger, L.M.; Moore, J.R.; Vockenhuber, C.; Aaron, J.; Hajdas, I.; Ivy-Ochs, S. Two Early Holocene Rock Avalanches in the Bernese Alps (Rinderhorn, Switzerland). Geomorphology 2016, 268, 207-221. [CrossRef]

25. Aksay, S.; Ivy-Ochs, S.; Hippe, K.; Grämiger, L.; Vockenhuber, C. Slope Failure in a Period of Increased Landslide Activity: Sennwald Rock Avalanche, Switzerland. Geosciences 2021, 11, 331. [CrossRef]

26. Ivy-Ochs, S.; Martin, S.; Campedel, P.; Hippe, K.; Vockenhuber, C.; Carugati, G.; Rigo, M.; Pasqual, D.; Viganò, A. Geomorphology and Age of Large Rock Avalanches in Trentino (Italy): Castelpietra. In Proceedings of the 4th World Landslide Forum: Landslide Research and Risk Reduction for Advancing the Culture of Living with Natural Hazards, Ljubljana, Slovenia, 29 May-2 June 2017; pp. 347-353. [CrossRef]

27. Oetheimer, C. Etude Géomorphologique Des Éboulements Remaniés de La Vallée de Tovel: Contribution à La Connaissance Des «marocche» Du Trentin (Italie). Studi trentini di scienze naturali. Acta Geol. 1989, 65, 3-47.

28. Perna, G. Itinerari geologici: La Marocca Di Gorte. Econ. Trent. 1991, 4, 65-88.

29. Perna, G. Inquadramento Cronologico Delle Grandi Frane Quaternarie Delle Valli Dei Laghi e Del Basso Sarca. Econ. Trent. 1996, 3, 55-89.

30. Martin, S.; Campedel, P.; Ivy-Ochs, S.; Viganò, A.; Alfimov, V.; Vockenhuber, C.; Andreotti, E.; Carugati, G.; Pasqual, D.; Rigo, M. Lavini Di Marco (Trentino, Italy): 36Cl Exposure Dating of a Polyphase Rock Avalanche. Quat. Geochronol. 2014, 19, 106-116. [CrossRef]

31. Orombelli, G.; Sauro, U. I Lavini Di Marco: Un Gruppo Di Frane Oloceniche Nel Contesto Morfoneotettonico Dell'alta Val Lagarina (Trentino). Suppl. Geogr. Fis. Din. Quat. 1988, 1, 107-116.

32. Castellarin, A.; Vai, G.B.; Cantelli, L. The Alpine Evolution of the Southern Alps around the Giudicarie Faults: A Late Cretaceous to Early Eocene Transfer Zone. Tectonophysics 2006, 414, 203-223. [CrossRef]

33. Picotti, V.; Prosser, G.; Castellarin, A. Structures and Kinematics of the Giudicarie-Val Trompia Fold and Thrust Belt (Central Southern Alps, Northern Italy). Mem. Sci. Geol. 1995, 47, 95-109.

34. Bini, A.; Cita, M.B.; Gaetani, M. Southern Alpine Lakes-Hypothesis of an Erosional Origin Related to the Messinian Entrenchment. Mar. Geol. 1978, 27, 271-288. [CrossRef]

35. Finckh, P.G. Are Southern Alpine Lakes Former Messinian Canyons?-Geophysical Evidence for Preglacial Erosion in the Southern Alpine Lakes. Mar. Geol. 1978, 27, 289-302. [CrossRef]

36. Winterberg, S.; Picotti, V.; Willett, S.D. Messinian or Pleistocene Valley Incision within the Southern Alps. Swiss J. Geosci. 2020 113, 1-14. [CrossRef]

37. Viganò, A.; Bressan, G.; Ranalli, G.; Martin, S. Focal Mechanism Inversion in the Giudicarie-Lessini Seismotectonic Region (Southern Alps, Italy): Insights on Tectonic Stress and Strain. Tectonophysics 2008, 460, 106-115. [CrossRef]

38. Viganò, A.; Scafidi, D.; Ranalli, G.; Martin, S.; della Vedova, B.; Spallarossa, D. Earthquake Relocations, Crustal Rheology, and Active Deformation in the Central-Eastern Alps (N Italy). Tectonophysics 2015, 661, 81-98. [CrossRef]

39. Guidoboni, E.; Ferrari, G.; Tarabusi, G.; Sgattoni, G.; Comastri, A.; Mariotti, D.; Ciuccarelli, C.; Bianchi, M.G.; Valensise, G. CFTI5Med, the New Release of the Catalogue of Strong Earthquakes in Italy and in the Mediterranean Area. Sci. Data 2019, 6, 1-15. [CrossRef]

40. Gasperini, L.; Marzocchi, A.; Mazza, S.; Miele, R.; Meli, M.; Najjar, H.; Michetti, A.M.; Polonia, A. Morphotectonics and Late Quaternary Seismic Stratigraphy of Lake Garda (Northern Italy). Geomorphology 2020, 371, 107427. [CrossRef]

41. Castellarin, A.; Trombetta, G.L.; Picotti, V.; Cantelli, L.; Claps, M.; Luigi, S.; Carton, A.; Borsato, A.; Daminato, F.; Nardin, M.; et al. Note Illustrative Della Carta Geologica d'Italia- Foglio 080 Riva Del Garda; APAT—Servizio Geologico d'Italia: Firenze, Italy, 2005.

42. Campedel, P.; Zumiani, M. Realizzazione Del Collegamento Stradale Passo Di San Giovanni_Località Cretaccio. Relazione Geologica; Pronvincia Autonoma di Trento: Trento, Italy, 2017.

43. Vacek, M. Geologische Spezialkarte Der Im Reichsrate Vertretenen Königreiche Und Länder Der Österreichisch-Ungarischen MonarchieZone 22, Col. IV, Rovereto Und Riva; K.K. Geologische Reichsanstalt: Wien, Austria, 1903.

44. Habbe, K.A. Die Würmzeitliche Vergletscherung Des Gardasee-Gebietes. Freibg. Geogr. Arb. 1969, 3, 254. 
45. Valle, C.; Santuliana, E. Opera Nr. 436. Collegamento "Loppio-Busa" Sulla S.S.240 e Circonvallazione Di Torbole. Progetto Preliminare e Studio V.I.A., Tavola Geologia, Relazione Geologica-Geotecnica; Provincia Autonoma di Trento: Trento, Italy, 2008.

46. Castellarin, A.; Cantelli, L. Neo-Alpine Evolution of the Southern Eastern Alps. J. Geodyn. 2000, 30, 251-274. [CrossRef]

47. Provincia Autonoma di Trento LIDA RRilievo 2006/2007/2008. Available online: http:/ /www.territorio.provincia.tn.it/portal/ server.pt/community/lidar/847/lidar/23954 (accessed on 21 August 2021).

48. Provincia Autonoma di Trento Carta Della Pericolosità e Carta Di Sintesi Della Pericolosità-Section N. 80110-Riva Del Garda; Provincia Autonoma di Trento: Trento, Italy, 2020.

49. Ivy-Ochs, S.; Kober, F. Surface Exposure Dating with Cosmogenic Nuclides. EG Quat. Sci. J. 2008, 57, 179-209. [CrossRef]

50. Ivy-Ochs, S.; Synal, H.A.; Roth, C.; Schaller, M. Initial Results from Isotope Dilution for Cl and 36Cl Measurements at the PSI/ETH Zurich AMS Facility. Nucl. Instrum. Methods Phys. Res. Sect. B Beam Interact. Mater. At. 2004, 223, 623-627. [CrossRef]

51. Christl, M.; Vockenhuber, C.; Kubik, P.W.; Wacker, L.; Lachner, J.; Alfimov, V.; Synal, H.A. The ETH Zurich AMS Facilities: Performance Parameters and Reference Materials. Nucl. Instrum. Methods Phys. Res. Sect. B Beam Interact. Mater. At. 2013, 294, 29-38. [CrossRef]

52. Vockenhuber, C.; Miltenberger, K.U.; Synal, H.A. 36Cl Measurements with a Gas-Filled Magnet at 6 MV. Nucl. Instrum. Methods Phys. Res. Sect. B Beam Interact. Mater. At. 2019, 455, 190-194. [CrossRef]

53. Synal, H.A.; Bonani, G.; Döbeli, M.; Ender, R.M.; Gartenmann, P.; Kubik, P.W.; Schnabel, C.; Suter, M. Status Report of the PSI/ETH AMS Facility. Nucl. Instrum. Methods Phys. Res. Sect. B Beam Interact. Mater. At. 1997, 123, 62-68. [CrossRef]

54. Alfimov, V.; Ivy-Ochs, S. How Well Do We Understand Production of 36Cl in Limestone and Dolomite? Quat. Geochronol. 2009, 4, 462-474. [CrossRef]

55. Stone, J.O.; Allan, G.L.; Fifield, L.K.; Cresswell, R.G. Cosmogenic Chlorine-36 from Calcium Spallation. Geochim. Cosmochim. Acta 1996, 60, 679-692. [CrossRef]

56. Stone, J.O.H.; Evans, J.M.; Fifield, L.K.; Allan, G.L.; Cresswell, R.G. Cosmogenic Chlorine-36 Production in Calcite by Muons. Geochim. Cosmochim. Acta 1998, 62, 433-454. [CrossRef]

57. Marrero, S.M.; Phillips, F.M.; Caffee, M.W.; Gosse, J.C. CRONUS-Earth Cosmogenic 36Cl Calibration. Quat. Geochronol. 2016, 31, 199-219. [CrossRef]

58. Balco, G.; Stone, J.O.; Lifton, N.A.; Dunai, T.J. A Complete and Easily Accessible Means of Calculating Surface Exposure Ages or Erosion Rates from 10Be and 26Al Measurements. Quat. Geochronol. 2008, 3, 174-195. [CrossRef]

59. Steinemann, O.; Ivy-Ochs, S.; Grazioli, S.; Luetscher, M.; Fischer, U.H.; Vockenhuber, C.; Synal, H.-A. Quantifying Glacial Erosion on a Limestone Bed and the Relevance for Landscape Development in the Alps. Earth Surf. Process. Landf. 2020, 45, 1401-1417. [CrossRef]

60. Scheidegger, A.E. On the Prediction of the Reach and Velocity of Catastrophic Landslides. Rock Mech. 1973, 5, 231-236. [CrossRef]

61. Hungr, O.; Evans, S.G.; Hazzard, J. Magnitude and Frequency of Rock Falls and Rock Slides along the Main Transportation Corridors of Southwestern British Columbia. Can. Geotech. J. 1999, 36, 224-238. [CrossRef]

62. Hungr, O.; Evans, S.G. Entrainment of Debris in Rock Avalanches: An Analysis of a Long Run-out Mechanism. Bull. Geol. Soc. Am. 2004, 116, 1240-1252. [CrossRef]

63. Aaron, J.; Hungr, O. Dynamic Simulation of the Motion of Partially-Coherent Landslides. Eng. Geol. 2016, 205, 1-11. [CrossRef]

64. McDougall, S.; Hungr, O. A Model for the Analysis of Rapid Landslide Motion across Three-Dimensional Terrain. Can. Geotech. J. 2004, 41, 1084-1097. [CrossRef]

65. Hungr, O.; McDougall, S. Two Numerical Models for Landslide Dynamic Analysis. Comput. Geosci. 2009, 35, 978-992. [CrossRef]

66. Aaron, J.; McDougall, S.; Nolde, N. Two Methodologies to Calibrate Landslide Runout Models. Landslides 2019, 16, 907-920. [CrossRef]

67. Provincia Autonoma di Trento Reticolo Idrografico. Available online: https:/ /webgis.provincia.tn.it/ (accessed on 21 August 2021).

68. Baroni, C. Lake Garda: An Outstanding Archive of Quaternary Geomorphological Evolution. In Landscapes and Landforms of Italy; Soldati, M., Marchetti, M., Eds.; Springer: Berlin/Heidelberg, Germany, 2017; pp. 169-179.

69. Sosio, R.; Crosta, G.B.; Hungr, O. Complete Dynamic Modeling Calibration for the Thurwieser Rock Avalanche (Italian Central Alps). Eng. Geol. 2008, 100, 11-26. [CrossRef]

70. Si, P.; Aaron, J.; McDougall, S.; Lu, J.; Yu, X.; Roberts, N.J.; Clague, J.J. A Non-Hydrostatic Model for the Numerical Study of Landslide-Generated Waves. Landslides 2017, 15, 711-726. [CrossRef]

71. Dufresne, A.; Davies, T.R. Longitudinal Ridges in Mass Movement Deposits. Geomorphology 2009, 105, 171-181. [CrossRef]

72. Von Poschinger, A.; Ruegg, T. Die Churer Tomahügel, Ein Besonderes Zeugnis Der Landschaftsgenese. Jahresbericht der Naturforschenden Gesellschaft Graubünden 2012, 117, 93-100.

73. Prager, C.; Ivy-Ochs, S.; Ostermann, M.; Synal, H.A.; Patzelt, G. Geology and Radiometric 14C-, 36Cl- and Th-/U-Dating of the Fernpass Rockslide (Tyrol, Austria). Geomorphology 2009, 103, 93-103. [CrossRef]

74. Montandon, F. Chronologie Des Grands Éboulements Alpins Du Début de l'ère Chrétienne à Nos Jours. Matériaux Pour l'étude des Calamités 1933, 32, 271-340.

75. Monegato, G.; Scardia, G.; Hajdas, I.; Rizzini, F.; Piccin, A. The Alpine LGM in the Boreal Ice-Sheets Game. Sci. Rep. 2017, 7, 2078. [CrossRef] 
76. Ravazzi, C.; Pini, R.; Badino, F.; de Amicis, M.; Londeix, L.; Reimer, P.J. The Latest LGM Culmination of the Garda Glacier (Italian Alps) and the Onset of Glacial Termination. Age of Glacial Collapse and Vegetation Chronosequence. Quat. Sci. Rev. 2014, 105, 26-47. [CrossRef]

77. Wolter, A.; Stead, D.; Ward, B.C.; Clague, J.J.; Ghirotti, M. Engineering Geomorphological Characterisation of the Vajont Slide, Italy, and a New Interpretation of the Chronology and Evolution of the Landslide. Landslides 2016, 13, 1067-1081. [CrossRef]

78. Provincia Autonoma di Trento Catasto Grotte. Available online: https://webgis.provincia.tn.it/ (accessed on 21 August 2021).

79. Pánek, T.; Hradecký, J.; Šilhán, K.; Smolková, V.; Altová, V. Time Constraints for the Evolution of a Large Slope Collapse in Karstified Mountainous Terrain of the Southwestern Crimean Mountains, Ukraine. Geomorphology 2009, 108, 171-181. [CrossRef]

80. Sauro, F.; Zampieri, D.; Filipponi, M. Development of a Deep Karst System within a Transpressional Structure of the Dolomites in North-East Italy. Geomorphology 2013, 184, 51-63. [CrossRef]

81. Gutiérrez, F.; Parise, M.; de Waele, J.; Jourde, H. A Review on Natural and Human-Induced Geohazards and Impacts in Karst. Earth Sci. Rev. 2014, 138, 61-88. [CrossRef]

82. Viganò, A.; Scafidi, D.; Martin, S.; Spallarossa, D. Structure and Properties of the Adriatic Crust in the Central-Eastern Southern Alps (Italy) from Local Earthquake Tomography. Terra Nova 2013, 25, 504-512. [CrossRef]

83. Martin, S.; Ivy-Ochs, S.; Viganò, A.; Campedel, P.; Rigo, M.; Vockenhuber, C.; Gabrieli, F.; Mair, V.; Rossato, S. Landslides of the Western Dolomites: Case Studies from the Adige and Sarca Valleys (NE Italy). Alp. Mediterr. Quat. 2020, 33, 191-207. [CrossRef]

84. Rossato, S.; Fontana, A.; Mozzi, P. Meta-Analysis of a Holocene 14C Database for the Detection of Paleohydrological Crisis in the Venetian-Friulian Plain (NE Italy). Catena 2015, 130, 34-45. [CrossRef]

85. Benito, G.; Macklin, M.G.; Panin, A.; Rossato, S.; Fontana, A.; Jones, A.F.; Machado, M.J.; Matlakhova, E.; Mozzi, P.; Zielhofer, C. Recurring Flood Distribution Patterns Related to Short-Term Holocene Climatic Variability. Sci. Rep. 2015, 5, 1-8. [CrossRef]

86. Gischig, V.; Preisig, G.; Eberhardt, E. Numerical Investigation of Seismically Induced Rock Mass Fatigue as a Mechanism Contributing to the Progressive Failure of Deep-Seated Landslides. Rock Mech. Rock Eng. 2016, 49, 2457-2478. [CrossRef]

87. Loew, S.; Gschwind, S.; Gischig, V.; Keller-Signer, A.; Valenti, G. Monitoring and Early Warning of the 2012 Preonzo Catastrophic Rockslope Failure. Landslides 2017, 14, 141-154. [CrossRef]

88. Bartlein, P.J.; Harrison, S.P.; Brewer, S.; Connor, S.; Davis, B.A.S.; Gajewski, K.; Guiot, J.; Harrison-Prentice, T.I.; Henderson, A.; Peyron, O.; et al. Pollen-Based Continental Climate Reconstructions at 6 and $21 \mathrm{Ka:}$ A Global Synthesis. Clim. Dyn. 2011, 37, 775-802. [CrossRef]

89. Routson, C.C.; McKay, N.P.; Kaufman, D.S.; Erb, M.P.; Goosse, H.; Shuman, B.N.; Rodysill, J.R.; Ault, T. Mid-Latitude Net Precipitation Decreased with Arctic Warming during the Holocene. Nature 2019, 568, 83-87. [CrossRef] 